\begin{tabular}{|l|l|}
\hline 2. To: (Receiving Organization) & 3. From: Coriginating Organization) \\
Distribution & 324 Subprojects Projects \\
\hline 5. Proj./Prog./Dept./Div.: & 6. Design Authority/ Design Agent/Cog. \\
19350 & Engr.: \\
\hline
\end{tabular}

8. Originator Remarks:

For Approval and Release

11. Receiver Renarks: 11A. Design Basel ine Document? [] Yes [X] No

\begin{tabular}{l|r} 
3. From: (Originating Organization) & 4. Related EDT No.: \\
324 Subprojects Projects & N/A
\end{tabular}

7. Purchase Order No.:

$\mathrm{N} / \mathrm{A}$

9. Equip./Component No.:

$\mathrm{N} / \mathrm{A}$

10. System/Bldg./Facil ity: 324 Building

12. Major Assm. Dwg. No.:

N/A

13. Permit/Permit Application No.: N/A

14. Required Response Date: $7 / 30 / 98$

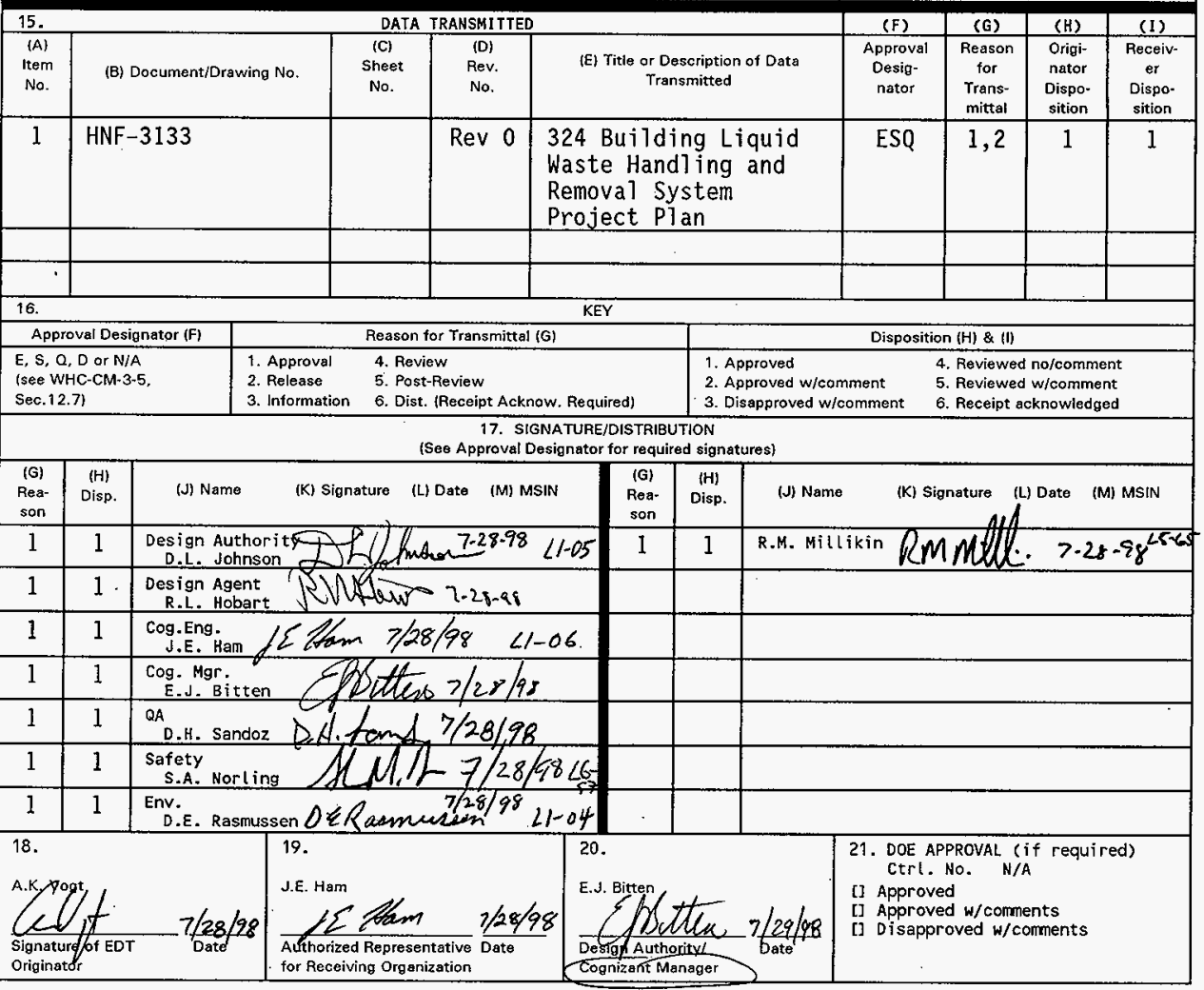




\title{
324 Building Liquid Waste Handling and Removal System Project Plan
}

JE Ham

Babcock \& Wilcox Hanford Co. , Richland, WA 99352

U.S. Department of Energy Contract DE-AC06-96RL13200

\author{
EDT/ECN: 625233 \\ UC: 2050 \\ Org Code: 19350 \\ B\&R Code: EX7050000 \\ Charge Code: K4BR1/A41098 Line Item 83 \\ Total Pages: 54
}

Key Words: 324 Building, Radiological, Liquid, Waste, Modification, Options

Abstract: This report evaluates the modification options for handiing radiological Tiquid waste generated during decontamination and cleanout of the 324 Building.

TRADBMARK DISCLAIMER. Reference herein to any specific commercial product, process, or service by trade name, tracemark, manufacturer, or otherwise, does not necessarily constitute or imply its endorsement, recomendation, or favoring by the United States Government or any agency thereof or its contractors or subcontractors.

Printed in the United States of America. To obtain copies of this document, contact: Document Control Services, P.O. Box 950, Mailstop H6-08, Richland WA 99352, Rhone (509) 372-2420; Pax (509) 376-4989.
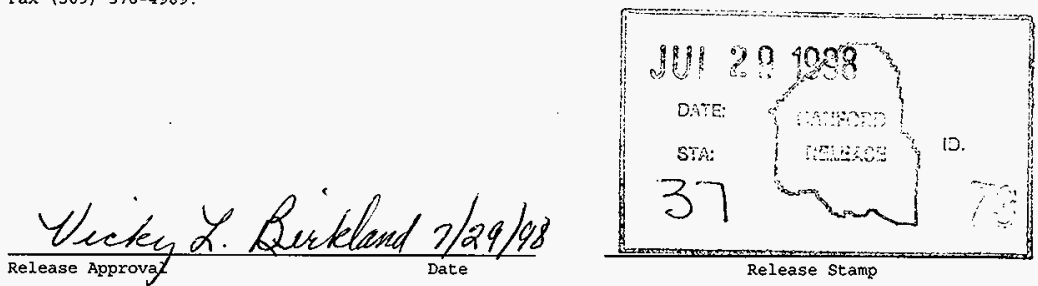
HNF-3133, Rev. 0

\section{Building \\ Liquid Waste Handling and Removal System \\ Project Plan}

Rev. 0

July 8, 1998

Prepared for:

B\& W Hanford Company

P.O. Box 1200

Richland, Washington 99352

Prepared by:

Parsons Infrastructure \& Technology Group, Inc. 1955 Jadwin Ave

Richland Washington 99352 
HNF-3133, Rev. 0

\section{Table of Contents}

1.0 OBJECTIVE AND BACKGROUND...........................................................................4

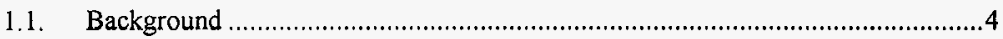

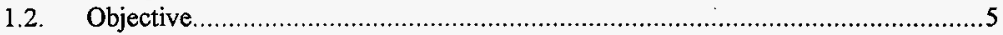

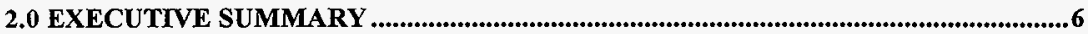

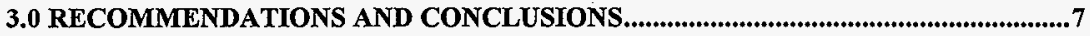

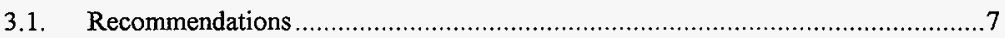

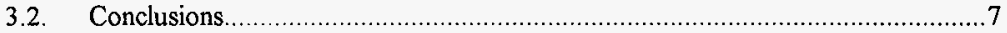

4.0 UNCERTANTIES AND ASSUMPTIONS ...........................................................................

5.0 DESCRIPTION OF FACLITY SYSTEMS AND EQUIPMENT .................................13

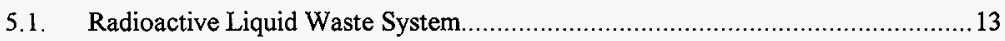

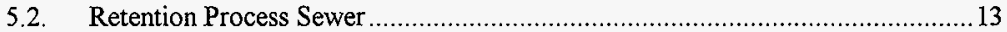

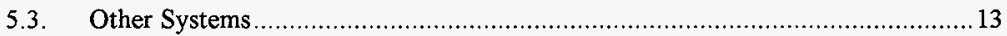

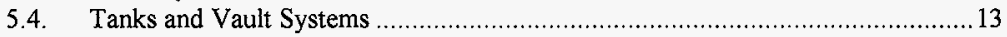

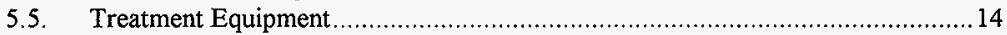

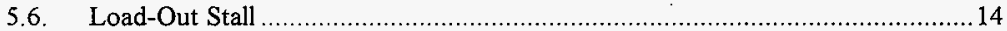

5.7. Wastewater Characterization .................................................................. 14

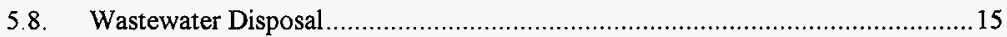

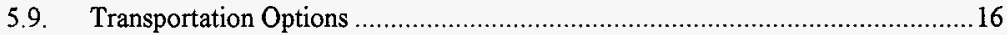

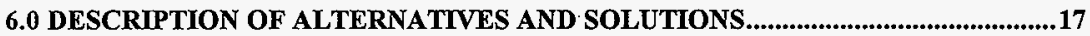

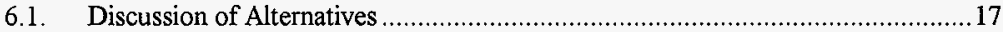

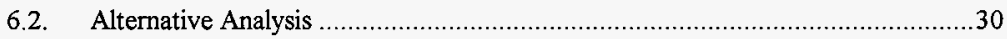

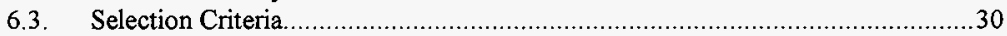

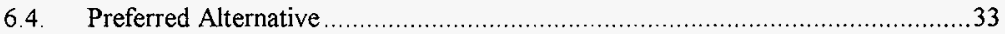

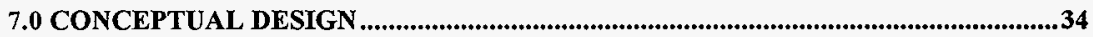

7.1. Project Scope

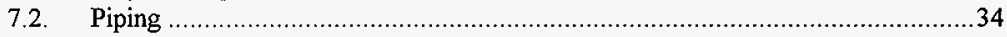

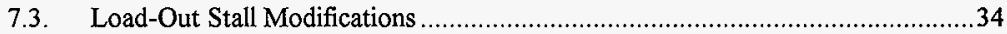

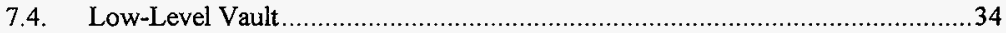

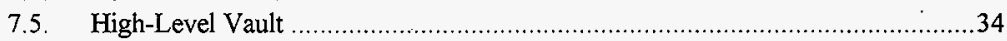

7.6. Treatment Skid Maintenance/Modifications ..................................................35

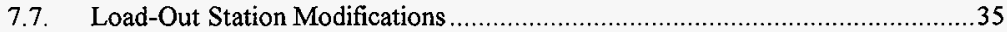

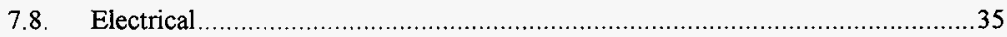

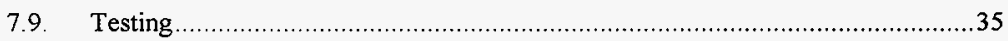




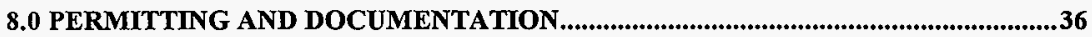

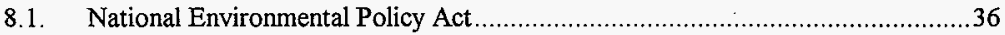

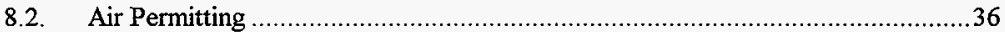

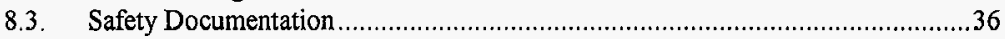

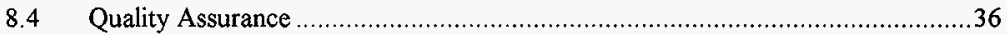

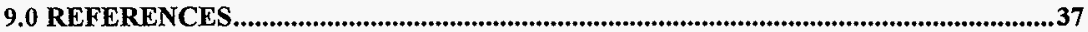

Figures

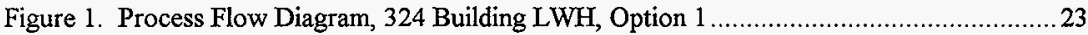

Figure 2. Process Flow Diagram, 324 Building LWH, Option 2 ..........................................24

Figure 3. Process Flow Diagram, 324 Building LWH, Option 3 ...................................25

Figure 4. Process Flow Diagram, 324 Building LWH, Option 4 ...........................................26

figure 5 Process Flow Diagram, 324 Building LWH, Option 5 .................................... 27

Figure 6. Process Flow Diagram, 324 Building LWH, Option 6 ........................................2 28

Figure 7. Process Flow Diagram, 324 Building LWH, Option 7 ...................................... 29

\section{$\underline{\text { Tables }}$}

Table 1. Estimated Liquid Waste Volumes Generated by Deactivation by Building Area...........11

Table 2. Estimated Radioactive Holdup and Flush Water Activity........................................12

Table 3. Treatment Skid Location Advantages/Disadvantages. ............................................. 18

Table 4. Wastewater Collection Location Advantages/Disadvantages. ...................................19

Table 5. Wastewater Staging Location Advantages/Disadvantages. ......................................19

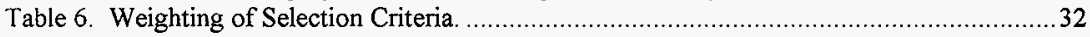


HNF-3133, Rev. 0

\subsection{OBJECTIVE AND BACKGROUND}

\subsection{Background}

The 324 Building Stabilization Project will establish a passively safe and environmentally secure configuration of the 324 Building [See 324/327 Buildings Stabilization/Deactivation Project Management Plan (HNF-IP-1289, Rev 0)]. To accomplish this goal, liquid decontamination has been proposed for certain areas within the building. Wastewater generated from this decontamination effort is anticipated to contain levels of radioactivity and State of Washington designated dangerous waste, which without treatment, would pose ALARA concerns and transportation issues.

In the past, these issues were mitigated by collecting the wastewater in the 324 Building Radioactive Liquid Waste System (RLWS) and the Low-Level Vault (LLV) tanks where it would be staged prior to transferring through a series of piping to the 340 Facility. After receipt of the wastewater at the 340 Facility it would be staged until it was loaded into a rail tanker and transferred to the 200 Area Tank Farm system through the 204-AR Facility.

The 340 Facility is more than 40 years old and does not have a dangerous waste permit as a treatment, storage and disposal (TSD) facility. The current planning baseline forecasts closure of the 340 Facility by the end of FY 1998 . Consequently, the 340 Facility will not be available to accept radioactive liquid waste that is generated during the deactivation of the 324 Building. Recent discussions, with DynCorp Tri-Cities Services, Inc., indicate that the Hanford site railroad system will be closed by the end of FY 1998 also necessitating the need for an alternate transfer method. The issue of handling of Radioactive Liquid Waste (RLW) from the 324 Building (assuming the 340 Facility is not available to accept the RLW) has been examined in at least two earlier engineering studies (Parsons 1997a and Hobart 1997). Each study identified a similar preferred alternative that included modifying the 324 Building RLWS to allow load-out of wastewater to a truck tanker, while making maximum use of existing piping, tanks, instrumentation, controls and other features to minimize costs and physical changes to the building. This alternative is accepted as the basis for further discussion presented in this study.

The goal of this engineering study is to verify the pathforward presented in the previous studies and assure that the selected alternative satisfies the 324 Building deactivation goals and objectives as currently described in the project management plan. This study will also evaluate options available to implement the preferred alternative and select the preferred option for implementation of the entire system. Items requiring further examination will also be identified. Finally, the study will provide a conceptual design, schedule and cost estimate for the required modifications to the 324 Building to allow removal of RLW. Attachment 5 is an excerpt from the project baseline schedule found in the Project Management Plan. 
HNF-3133, Rev. 0

\subsection{Objective}

Provide a detailed approach to the preferred alternative for removal of radioactive wastewater generated during the deactivation of the 324 Building. Based on the approach selected in earlier studies provide the most cost effective option to meet the project objectives and goals. Provide a conceptual design and cost estimate for dispositioning the 324 Building radioactive liquid waste. 


\subsection{EXECUTIVE SUMMARY}

Two goals for the deactivation of the 324 Building are to eliminate, reduce, shield or isolate radiation fields, and to eliminate hazards, nuclear and non-nuclear, by removing, isolating, draining and minimizing hazardous materials. This study details the wastewater removal approach selected in the previous two engineering studies. The approach selected is to modify the 324 Building RLWS to allow pretreatment and load-out of wastewater to truck tanker to meet the 324 Building deactivation goals and objectives.

To implement the preferred alternative and meet the 324 Building deactivation goals many combinations of collection and storage, treatment location and staging prior to load-out exist. A total of seven options were evaluated in this study. These options studied different combinations for the location of the primary activities performed within the plant. Primary activities are collection, treatment and staging prior to load-out; all alternatives include truck load-out exterior to the building. The options are as follows:

- Option 1: B Cell Collection, D Cell Treatment, LLV Staging

- Option 2: HLV Collection, Airlock Treatment, LLV Staging

- Option 3: HLV Collection, LLV Treatment, LLV Staging

- Option 4: HLV Collection, C Cell Treatment, LLV Staging

- Option 5: HLV Collection, D Cell Treatment, LLV Staging

- Option 6: LLV Collection, LOS Treatment, LOS Staging

- Option 7: HLV Collection, LOS Treatment, LLV Staging

From the evaluation performed in this study, Option 7 has been selected to most effectively satisfy the necessary functions For the purpose of this study option 7 will be evaluated and estimated.

Option 7 maximizes the use of existing tanks, piping and building equipment while minimizing the impact to building decontamination efforts. This option utilizes the High-Level Vault (HLV) tanks for collection of the decontamination wastewater, Load Out Stall (LOS) for wastewater treatment, the Low-Level Vault (LLV) tanks for treated wastewater staging prior to load-out and a truck load-out station exterior to the building.

This study recommends that further investigation into the decontamination approach applied to the REC hot cells, specifically B and D Cells be performed, prior to the selection/procurement of the treatment unit. The information received from this investigation will allow the development of design parameters for the treatment skid that are not currently available.

The preliminary cost estimate for the preferred option (Option 7) is approximately $\$ 900,000$. The details of this estimate are included in Attachment 4. The estimate includes costs for engineering, project management, site work, procurement and construction of a truck loading facility. 


\subsection{RECOMMENDATIONS AND CONCLUSIONS}

\subsection{Recommendations}

This study recommends that B\&W Hanford Company (BWHC) install a truck load-out station exterior to the building, supported by in plant piping modifications to allow collection of decontamination wastewater in the HLV; treatment in the LOS by a vendor supplied treatment skid; and staging prior to load-out in the LLV.

The study also recommends that BWHC undertake a characterization study of the B Cell and other highly contaminated areas to provide a sound technical basis for the building decontamination approach and to provide a strong basis to select and design the water treatment system.

The alternative also utilizes existing facilities, piping, and tanks and equipment to the extent possible and use of the LR-56 tank truck to transport waste to an on-site treatment, storage or disposal unit (TSD).

This option requires $B W H C$ to proceed with modifications to the closure plan in order to ensure use of the HLV tanks for collection and storage prior to treatment.

\subsection{Conclusions}

Option 7, HLV collection, LOS treatment and LLV staging prior to load-out, has been selected and provides the best overall solution to meet the 324 Building deactivation goals while having the least impact on other plant operations and activities required for deactivation. Utilization of the existing vaults, and transfer piping associated with the vault system substantially limits the new piping necessary to achieve the project goals. 
HNF-3133, Rev. 0

\subsection{UNCERTANTIES AND ASSUMPTIONS}

The following is a discussion of uncertainties generated during the writing of this report. For each uncertainty, there is an explanation of the reasons for the uncertainty or why an assumption is justified, followed by the enabling assumption.

\section{Uncertainty 1}

Will the water generated during deactivation be acceptable for on-site shipment and Treatment/Storage/Disposal?

Contamination levels currently found in the building and projected wastewater volumes to be generated indicate that the wastewater will exceed the acceptance criteria of the LR-56 tank trailer and the 204-AR Facility.

\section{Assumption 1}

Wastewater will require pretreatment prior to shipment to meet the LR-56 Tank Truck and Double Shell Tanks Acceptance Criteria

\section{Uncertainty 2}

What will be the volume of radioactive liquid waste generated from various deactivation activities?

The 324/327 Buildings Stabilization/Deactivation Project Management Plan provides the basis for the wastewater volume anticipated to be generated during facility deactivation. An investigation to determine the actual decontamination approach for specific facility areas is recommended to reduce the uncertainty associated with this wastewater volume estimate. Other decontamination methods may be selected that do not use water or use much greater volumes of water as a basis that could seriously impact the ratio of water to radioactivity changing the treatment requirements for acceptance of the liquid on site.

\section{Assumption 2}

The volumes listed in Table 1 will be used as the basis for the volume of radioactive liquid waste generated from various deactivation activities

\section{Uncertainty 3}

What will the liquid radioactive waste characterization and curie concentration be following the various deactivation activities? 
Initial facility characterization and discussions with facility personnel were used to develop the estimated curie loading of the wastewater prior to treatment. Based on the estimated volume of 221,239 liters (58,452 gallons), (Table 1), and the estimated 314,007 curies of radioactivity, (Table 2$)$, the resulting wastewater will average $1.4 \mathrm{Ci} / 1(5.4 \mathrm{Ci} / \mathrm{gal})$ prior to treatment with the maximum curie loading coming from $\mathrm{B}$ Cell activities that could exceed $5.7 \mathrm{Ci} / \mathrm{Liter}(21.7 \mathrm{Ci} / \mathrm{gal})$. An investigation to provide quantifiable radioactive holdup estimate is recommended to reduce the uncertainty associated with this estimate.

\section{Assumption 3}

The radioactive liquid waste, generated from deactivation activities, will have an average and maximum curie concentration of $1.4 \mathrm{Ci} / 1$ and $5.7 \mathrm{Ci} / 1$, respectively.

\section{Uncertainty 4}

Are the existing tanks and piping available for use, and will the regulators allow this approach?

The 324 Closure Plan discusses the use of existing plant piping, tanks and equipment for facility deactivation. A discussion of the use of the HLV tanks for collection and storage of decontamination wastewater will need to be added to the Closure Plan if it does not already exist. Approval of this closure plan by the Washington State Department of Ecology provides the necessary authorization to use the existing equipment, piping and tanks.

\section{Assumption 4}

All existing tanks and piping can be used for the effort. This includes use of the HLV tanks that have had previous closure activities.

\section{Uncertainty 5}

Shielded Materials Facility (SMF) does not directly connect to the building RLWS and Vault system, will the decontamination wastewater from SMF require treatment and load-out.

The current planning basis is that SMF will use a vendor supplied decontamination unit to provide most of the decontamination in this area. The vendor unit will provide neutralization of the decontamination solution and removal of the majority of the radioactive material. The water volume that requires disposal will need to be removed from the building. SMF clean-out activities will provide temporary piping to route wastewater to the LLV or RLWS. A 99\% removal efficiency of the radioactive material is expected. The water volume and curie loading from the SMF deactivation are found in Tables 1 and 2. 
HNF-3133, Rev. 0

\section{Assumption 5}

SMF water volume will be included in total wastewater inventory but the radioactivity will be reduced by $99 \%$ due to treatment by vendor unit.

\section{Uncertainty 6}

Can the $D$ Cell equipment be made operational and will it have the durability to treat all the wastewater generated by deactivation activities?

D Cell water treatment equipment was designed and constructed for a specific one-time use to treat a limited quantity of a specific waste stream. It is not known whether the skid will be able to treat a quantity of waste much greater than its intended use. The durability of the skid is of concern. The cost of refurbishment and maintenance may out weigh the cost of procuring a new treatment system. Also the need to decontaminate the existing skid in order to remove the unit from D Cell may not be cost effective

\section{Assumption 6}

D Cell equipment, with moderate maintenance and decontamination will be used to support all treatment options within the building only if the unit remains in the Radiochemical Engineering Complex (REC). A new unit will be procured if located out side of the REC. 
Table 1. Estimated Liquid Waste Volumes Generated by Deactivation by Building Area.

\begin{tabular}{|c|c|c|}
\hline Liquid Waste Source by Area & BOE Reference* & RLW Volume \\
\hline 324 RLWS \& RPS & $1 \mathrm{~K} 4 \mathrm{Z} 120 \mathrm{~A} 05$ & 6,056 liters $(1,600 \mathrm{gal})$ \\
\hline 324 HVAC Hot Side & $1 \mathrm{~K} 4 \mathrm{Z} 040 \mathrm{~A} 01$ & 379 liters (100 gal) \\
\hline $324 \mathrm{POG} / \mathrm{AOG} / \mathrm{VV}$ & $1 \mathrm{~K} 4 \mathrm{Z} 040 \mathrm{~A} 03$ & 757 liters (200 gal) \\
\hline 324 A Cell & $1 \mathrm{~K} 4 \mathrm{Z} 070 \mathrm{~A} 01$ & 12,491 liters $(3,300$ gal $)$ \\
\hline 324 B Cell & 1K4B0J0A01 & 52,233 liters $(13,800$ gal $)$ \\
\hline $324 \mathrm{C}$ Cell & $1 \mathrm{~K} 4 \mathrm{Z} 070 \mathrm{E} 01$ & 8,743 liters $(2,310 \mathrm{gal})$ \\
\hline 324 D Cell & $1 \mathrm{~K} 4 \mathrm{Z} 070 \mathrm{G} 01$ & 12,112 liters $(3,200 \mathrm{gal})$ \\
\hline 324 Airlock & $1 \mathrm{~K} 4 Z 070 y_{01}$ & 14,383 liters ( 3,800 gal) \\
\hline $324 \mathrm{HLV}$ & $1 \mathrm{~K} 4 \mathrm{Z} 070 \mathrm{~N} 01$ & 41,525 liters $(10,971 \mathrm{gal})$ \\
\hline $324 \mathrm{LLV}$ & $1 \mathrm{~K} 4 \mathrm{Z} 070 \mathrm{~N} 03$ & 14,421 liters $(3,810 \mathrm{gal})$ \\
\hline SMF South Cell & $1 \mathrm{~K} 4 \mathrm{Z} 080 \mathrm{~A} 01$ & 29,977 liters $(7,920$ gal $)$ \\
\hline SMF East Cell & $1 \mathrm{~K} 4 \mathrm{Z} 080 \mathrm{C} 01$ & 13,248 liters $(3,500 \mathrm{gal})$ \\
\hline SMF Airlock & $1 \mathrm{~K} 4 \mathrm{Z} 080 \mathrm{E} 01$ & 13,248 liters $(3,500 \mathrm{gai})$ \\
\hline SMF Cell Operating Gallery & $1 \mathrm{~K} 4 \mathrm{Z110G01}$ & 189 liters ( $50 \mathrm{gal}$ ) \\
\hline 324 Large Equipment Labs & 1K4Z050A01 & 114 liters $(30 \mathrm{gal})$ \\
\hline 324 Basement & $1 \mathrm{~K} 4 \mathrm{Z} 020 \mathrm{~A} 01$ & 1,363 liters ( $360 \mathrm{gal}$ ) \\
\hline Total & & 221,239 liters $(58,452$ gal $)$ \\
\hline
\end{tabular}

*324/327 Buildings Stabilization/Deactivation Project Management Plan (HNF-IP-1289, Rev 0) 
Table 2. Estimated Radioactive Holdup and Flush Water Activity.

\begin{tabular}{|l|c|c|}
\hline \multicolumn{1}{|c|}{ Facility Area } & $\begin{array}{c}\text { Estimated Cs-137 Holdup } \\
\text { Before Decontamination' } \\
\text { (Curies) }\end{array}$ & $\begin{array}{c}\text { Estimated Radioactivity in } \\
\text { flush water }{ }^{2} \text { (Curies) }\end{array}$ \\
\hline 324 RLWS \& RPS & Negligible & Negligible \\
\hline 324 HVAC Hot Side & Negligible & Negligible \\
\hline 324 POG/AOG/VV & Negligible & Negligible \\
\hline 324 A Cell & Negligible & Negligible \\
\hline 324 B Cell & $1,500,000^{6}$ & 300,000 \\
\hline 324 C Cell & Negligible & Negligible \\
\hline 324 D Cell & $9,985^{3}$ & 1,997 \\
\hline 324 Airlock & $10,000^{6}$ & 2,000 \\
\hline 324 HLV & $10,000^{7}$ & $10,000^{8}$ \\
\hline 324 LLV & Negligible & Negligible \\
\hline SMF South Cell & 1,000 & $10^{4}$ \\
\hline SMF East Cell & $0^{5}$ & $0^{5}$ \\
\hline SMF Airlock & $0^{5}$ & $0^{5}$ \\
\hline SMF Cell Operating Gallery & $0^{5}$ & $0^{5}$ \\
\hline 324 Large Equipment Labs & Negligible & Negligible \\
\hline 324 Basement & Negligible & Negligible \\
\hline Total & $1,530,985$ & 314,007 \\
\hline
\end{tabular}

Curies are based on most prevalent contaminate Cs-137

2 Assumes $80 \%$ removal efficiency by "dry" chemical foam and wipe down and $20 \%$ removal by flush water, unless otherwise specified

3 Based on 1 curie $/ 100 \mathrm{~cm}^{2}$ of surface area

${ }^{4}$ Based on $99 \%$ removal efficiency by vendor supplied decontamination unit

5 All SMF curie estimates are included in the SMF South Cell Total

6 Data based on the 324/327 Building Special Case Waste Assessment and Disposition Alternative Analysis HNF-1730 Rev. 1.

7 Estimate only no data available

8 No reduction in tank activity level is expected based on removal methods presented in the $324 \mathrm{High}-$ Level Vault and Low-Level Vault Engineering Study, Rev A. 


\subsection{DESCRIPTION OF FACILITY SYSTEMS AND EQUIPMENT}

The 324 Building contains two systems that transfer radioactive or potentially radioactive liquid waste to disposal: the Radioactive Liquid Waste System (RLWS) and the Retention Process Sewer (RPS). These two systems combined with the liquid transfer piping system within the building allow for significant options of routing water throughout the building.

\subsection{Radioactive Liquid Waste System}

The RLWS drains wastewater that has a high potential for radioactive contamination to the LLV tanks. Inputs to the RLWS are extensive in the Radioactively Controlled Areas of the building and include floor, sink and cell drains, tanks and sumps. Wastewater gravity drains to Tank 102 in the Low-Level Vault (LLV) system. There are 9 tanks associated with the RLWS: 4 HighLevel Vault (HLV) tanks, 4 LLV tanks and Tank 177. All tanks are directly or indirectly connected to the 300 Area RLWS. See attached sketch of the building RLWS (Attachment 1)

\subsection{Retention Process Sewer}

The RPS system drains wastewater that does not normally contain radioactive or hazardous materials to the 300 Area Process Sewer that connects to the 300 Area Treated Effluent Disposal Facility (TEDF) for treatment and release. Inputs to the RPS are extensive in the building and include floor drains, cooling and process systems laboratories that have a low potential for radioactive contamination. The RPS effluent is monitored for radioactive contamination, if radiation levels exceed a preset threshold, a 3-way valve diverts the flow to the RLWS system.

\subsection{Other Systems}

The 324 Building possesses a comprehensive piping system that allows transfer of liquid from cell to cell, vault to vault, cells to vauits and vaults to Load-Out Stall (LOS) (see Attachment 2). The system uses $90 \mathrm{psig}$ steam jets to transfer liquid from place to place. The system can be modified with pipe jumpers to allow nearly any configuration or routing of liquid within the building, if the routing does not already exist.

\subsection{Tanks and Vault Systems}

The building is equipped with two basic tank systems, the Low Level Vault and High-Level Vault systems. Each system contains 4 tanks and associated piping to allow filling, emptying and transferring among the tanks.

The LLV is comprised of tanks 101,102, 103 and 108. The LLV tanks have a total combined volume of 55,500 liters (14,661 gallons). The tanks range in size from 12,000 liters $(3,170$ gallons) to 18,500 liters (4,887 gallons). The tanks are contained in a rectangular concrete vault beneath the floor of the Engineering Development Laboratory (EDL), Room 147. The vault is lined with welded stainless-steel plates that provide secondary containment. The vault is covered 
with 0.6 meter thick $(2 \mathrm{ft}$ ) cover blocks. The radiation field strength within the vault is assumed to be very high.

The HLV is made up of tanks $104,105,106$ and 107. The HLV tanks have a total combined volume of 38,100 liters ( 10,055 gallons). The tanks range in size from 1,700 liters ( 450 gallons) to 18,000 liters $(4,755$ gallons). The tanks are contained in a rectangular concrete vault beneath the floor of the Cask Handling Area. The vault is lined with welded stainless-steel plates that provide secondary containment. The vault is covered with 1.8 meter thick $(5 \mathrm{ft})$ cover blocks. The radiation field strength within the vault is assumed to be very high.

\subsection{Treatment Equipment}

The 324 Building is equipped with a wastewater treatment unit used for HLV clean-out activities. This was installed in 1995 and was used for a relatively short period of time. The system is located in D Cell and consists of tanks, filtration, ion exchange and evaporation equipment. D Cell is a high radiation area and is also highly contaminated. For these reasons, the actual operational condition of the system is not known but it is assumed that with replacement of some radiation sensitive components the skid could be made operational.

\subsection{Load-Out Stall}

The Load-Out Stall (LOS) is located on the northeast side of the 324 Building near the Truck Lock. The LOS is a shielded (2-4" lead shielding) enclosure for loading and unloading radioactive liquids into and out of the HLV and LLV tanks. The ceiling is not shielded and is hinged on the west side so that it can be opened for crane access. The LOS has a large access door and a manipulator station with a leaded glass window. This area was traditionally used for transferring radioactive liquids to and from "bowling ball casks." The Cask Handling Area (CHA) near the LOS area is equipped with jet stations to allow transfers and sampling capability for the LLV tanks. Chemical addition capability exists for $\mathrm{pH}$ adjustment and neutralization in the CHA. No direct connection exists directly between the LOS and the REC Airlock and pipe trench.

\subsection{Wastewater Characterization}

The current planning basis, found in the PMP, for the deactivation of the radioactively contaminated area of the 324 Building is equipment removal and removal of dispersible material by mechanical methods followed by "dry" chemical foam and water flush for walls, floor and ceilings. Tanks will be decontaminated using chemical cleaning and water flush. The estimated volume of wastewater that will be generated during the building deactivation is found in Table 1. The radioactive material hold up that remains within the building after the equipment and dispersible removal activities are complete is expected to be extensive. Table 2 provides an estimate of the radioactive holdup by building area.

Based on the estimated volume of 221,239 liters ( 58,452 gallons), (Table 1), and the estimated 314,007 curies of radioactivity, (Table 2 ), the resulting wastewater will average $1.4 \mathrm{Ci} / 1$ 
(5.4Ci/gal) prior to treatment with the maximum curie loading coming from $\mathrm{B}$ Cell activities that could exceed $5.7 \mathrm{Ci} / \mathrm{Liter}(21.7 \mathrm{Ci} / \mathrm{gal})$. These factors are important to determine the amount of treatment necessary to achieve the acceptance of the wastewater by the other on-site organizations described in the following sections.

It is imperative that prior to the solicitation for and procurement of the wastewater treatment unit or modifications to the existing D Cell equipment, that the general decontamination approach for the building has been selected. The resulting wastewater from the different decontamination methods directly affects the treatment options available for the vendor supplied skid or the $D$ Cell equipment.

Other factors such as ion loading, total dissolved solids and residuals from decontamination solutions will be determined when information becomes available and prior to treatment unit specification development.

\subsection{Wastewater Disposal}

Three facilities currently exist on the Hanford Site that could treat, store and/or dispose of the liquid waste generated by the 324 Building deactivation activities. They are the 300 Area TEDF, the 200 Area Effluent Treatment Facility (ETF) and the 200 Area Tank Farms. Disposal of wastewater to any of these facilities is dependent on the waste characterization.

The 300 Area TEDF is the most restrictive facility for waste acceptance. The 300 Area TEDF can not dispose radioactive material that exceeds $15 \mathrm{pCi} / 1$ alpha and $50 \mathrm{pCi} / 1$ beta. Batch waivers are available for this facility but the radioactivity can not exceed the TEDF's Derived Concentration Guide (DCG) limits. The 327 Building is currently connected to this facility through the 300 Area Process Sewer system.

The 200 Area Effluent Treatment Facility (ETF) has a larger design envelope than the TEDF and can be adapted to accommodate certain waste streams. The waste is acceptable if it is; compatible with the Liquid Effluent Retention Facility (LERF) liners; does not exceed the building's bounding source term; and the waste stream is within the limits of the building's operating permit. The ETF has capability of receiving truck tanker transfer. Liquid waste received at the ETF is transferred from the load-out station and staged in the LERF prior to processing.

The 200 Area Tank Farms has the least restrictive waste acceptance criteria. Waste is transferred to the tank farms via the 204-AR Facility by rail tanker. The 204-AR Facility is the limiting factor for waste acceptance by the tank farms. This facility is currently being modified to accept truck tanker transfers. The tank farms can accept most liquid waste providing characterization and compatibility evaluations have been properly performed.

Actual acceptance criteria for these facilities can be found in the following documents:

- Treatment Effluent Disposal Facility, HNF-IP-1000; 
- $\quad$ Effluent Treatment Facility, ETF Treatability Envelop

- 200 Area Tank Farms, WHC-SD-WM-EV-053, Double-Shell Tank Waste Analysis Plan

\subsection{Transportation Options}

The Hanford Site is in possession of various truck tankers to transfer the liquid for treatment, storage and/or disposal. A brief description of some of the available transfer systems follows.

LR-56 is a shielded, self-contained tanker, that can carry up to 1,000 gallons of radioactive liquid. This tanker is designed for transporting liquid waste up to $1 \mathrm{Ci} / \mathrm{l}$ of radioactivity. Actual licensed and administrative controls are much lower, $0.5 \mathrm{Ci} / 1$. Modifications to the $204 \mathrm{AR}$ Facility to receive shipments from the LR-56 are currently underway.

There are three non-shielded 5,000-gal tankers on site owned by the ETF. These tankers are built and operated to U.S. Department of Transportation (DOT) Standards and can carry Low-Specific Activity Category II wastes (LSA II). This equates to approximately $0.13 \mathrm{Ci} / 1$ of $\mathrm{Cs}-137$ and $0.027 \mathrm{Ci} / \mathrm{l}$ of Sr-90. The curie limit for these tankers is substantially lower than the LR-56 tank trailer. They are capable of transporting liquid to the 200 Area Effluent Treatment Facility and off-loaded. 
HNF-3133, Rev. 0

\subsection{DESCRIPTION OF ALTERNATIVES AND SOLUTIONS}

\subsection{Discussion of Alternatives}

Many options for wastewater handling within the 324 Building exist. All of the options include a truck load-out station constructed adjacent to the exterior of the 324 Building, near the Truck Lock as determined in previous studies. This section discusses each option evaluated in this study.

It was determined that three primary activities would have to be performed for each option. They are wastewater collection and storage prior to treatment, wastewater treatment, and staging of treated wastewater prior to truck load-out. Building areas and equipment were identified that could satisfy or be modified to satisfy the activity. The building areas evaluated for each primary activity are listed below.

Wastewater collection and storage prior to treatment

B Cell

HLV

LLV

Wastewater Treatment

A Cell

C Cell

D Cell

Airlock

LLV

LOS

Staging Prior to truck load-out

LLV

LOS

Lists of advantages and disadvantages were compiled for each primary activity against the proposed building area. (Tables 3 through 5). Based on these lists, each area was ranked and a preference was assigned for its ability to achieve the primary activity (i.e., convenient piping, good shielding, existing equipment etc). 
Table 3. Treatment Skid Location Advantages/Disadvantages.

\begin{tabular}{|c|c|}
\hline \multicolumn{2}{|c|}{ Treatment Skid Location } \\
\hline Advantages & Disadvantages \\
\hline \multicolumn{2}{|l|}{ D Cell - Preference 3} \\
\hline Treatment Skid Exists & Very Contaminated Cell \\
\hline Shielded & $\begin{array}{l}\text { Manipulator operations required for maintenance and } \\
\text { equipment change-out }\end{array}$ \\
\hline $\begin{array}{l}\text { Good manipulator coverage in cell ( } 2 \\
\text { stations) }\end{array}$ & $\begin{array}{l}\text { Piping required if } \mathrm{B} \mathrm{Cell} \text { is used for collection to route } \\
\text { wastewater to skid }\end{array}$ \\
\hline Preferred if B Cell is used for collection & Pump required to move wastewater up to Cell \\
\hline \multicolumn{2}{|l|}{ A Cell-Preference 5} \\
\hline Clean Cell & Decontaminate existing or purchase treatment skid \\
\hline \multirow[t]{3}{*}{ Shielded } & $\begin{array}{l}\text { Manipulator operations required for maintenance and } \\
\text { equipment change-out }\end{array}$ \\
\hline & Not good manipulator coverage in cell (1 station) \\
\hline & Fuel/grout container storage planned for cell \\
\hline \multicolumn{2}{|l|}{ C Cell - Preference 1} \\
\hline Clean Cell - low background radiation & Decontaminate existing or purchase treatment skid \\
\hline Shielded & Cell not accessible by airlock crane \\
\hline \multicolumn{2}{|l|}{$\begin{array}{l}\text { No pump required to "lift" wastewater } \\
\text { to treatment skid from pipe trench }\end{array}$} \\
\hline \multicolumn{2}{|l|}{$\begin{array}{l}\text { Good manipulator coverage in cell ( } 2 \\
\text { stations) } \\
\text { Airlock - Preference } 4\end{array}$} \\
\hline \multicolumn{2}{|l|}{ Airlock-Preference 4} \\
\hline Shielded & Competes for airlock space/impacts other efforts \\
\hline Pipe trench in airlock & Decontaminate existing or purchase treatment skid \\
\hline \multirow[t]{3}{*}{$\begin{array}{l}\text { No extra pumping required to move } \\
\text { wastewater }\end{array}$} & Not good manipulator coverage (1 station) \\
\hline & Poor lighting in airlock \\
\hline & Access difficult (bubble suit required) \\
\hline \multicolumn{2}{|l|}{ LOS - Preference 2} \\
\hline Does not compete for space in REC & Lightly Shielded \\
\hline Not in high radiation area & Decontaminate existing or purchase treatment skid \\
\hline Lightly shielded & Pipe route from pipe trench to LOS does not exist \\
\hline \multicolumn{2}{|l|}{ LLV - Preference 6} \\
\hline Shielded & Tank Removal Required \\
\hline Close proximity to HLV and LLV tanks & Limits liquid retention capacity \\
\hline \multirow[t]{5}{*}{ Does not compete for space in REC } & Difficult change-out of filters and IX columns \\
\hline & Decontaminate existing or purchase treatment skid \\
\hline & Piping modifications in vault required \\
\hline & $\begin{array}{l}\text { Crane has been down rated to } 1 \text { ton would need to be } \\
\text { reassessed to } 5 \text { ton to remove cover blocks }\end{array}$ \\
\hline & Tanks and vault must be cleaned before installation 0 \\
\hline
\end{tabular}


Table 4. Wastewater Collection Location Advantages/Disadvantages.

\begin{tabular}{|l|l|}
\hline \multicolumn{2}{|l|}{ Untreated Wastewater Collection } \\
\hline Advantages & Disadvantages \\
\hline LLV - Preference 2 & Only 1 tank receives then distributes \\
\hline Shielded & \begin{tabular}{l} 
Eliminates use of LLV tanks for storage of treated \\
wastewater without piping modifications \\
\hline Large storage volume
\end{tabular} \\
\hline $\begin{array}{l}\text { High Radiation Area impact ability to perform } \\
\text { modifications }\end{array}$ \\
\hline $\begin{array}{l}\text { Tanks not "closed" } \\
\text { treating available to all parts of facility for }\end{array}$ & Mixing capability in the tanks may be marginal \\
\hline RPS diversion routed here & \\
\hline HLV - Preference 1 & Tanks "closed" \\
\hline Shielded & Poor to no mixing capability in tanks \\
\hline Extensive pipe routing to collect wastewater & No RPS diversion \\
\hline Large storage volume & \\
\hline Routing available to all parts of facility & \\
\hline $\begin{array}{l}\text { Allows LLV tanks to be used for staging } \\
\text { treated waste }\end{array}$ & \\
\hline B Cell - Preference 3 3 & New tank required \\
\hline Shielded & Schedule may conflict with other B Cell activities \\
\hline Simple routing to D Cell and treatment & $\begin{array}{l}\text { Manipulator operations required for maintenance and } \\
\text { equipment change-out }\end{array}$ \\
\hline $\begin{array}{l}\text { Tank will be designed to meet specific } \\
\text { operational needs }\end{array}$ & No RPS diversion \\
\hline
\end{tabular}

Table 5. Wastewater Staging Location Advantages/Disadvantages.

\begin{tabular}{|l|l|}
\hline \multicolumn{2}{|l|}{ Treated Wastewater Staging } \\
\hline Advantages & Disadvantages \\
\hline LLV - Preference 1 & Can't be used if used for untreated wastewater \\
\hline Large Volume & \\
\hline Direct piping to LOS & \\
\hline $\begin{array}{l}\text { Convenient collection routing from all parts } \\
\text { of the REC }\end{array}$ & \\
\hline LOS - Preference 2 & New tank required \\
\hline Close to load-out station & $\begin{array}{l}\text { Requires new line for routing liquid from treatment } \\
\text { skid }\end{array}$ \\
\hline Does not interfere with REC Operations \\
\hline
\end{tabular}


As a result, a set of options were developed from the list utilizing the building areas that appeared to satisfy the primary activities most completely and meet the goal of maximizing the use of existing piping, tanks, instrumentation, controls and other plant equipment (See Figures 1 through 7). Because some of the activities and areas are mutual exclusive, all combinations were not reviewed. For example B Cell for storage would only support D Cell treatment so B Cell storage was not evaluated for all the other treatment options. Only those options that had a high potential for implementation or were of sound engineering basis were evaluated. A discussion of each option follows.

Option 1. (Figure 1) B Cell Collection, D Cell Treatment and LLV Staging: This option would install a new tank in B Cell to collect the wastewater. The wastewater would be pumped or vacuum transferred from $B$ Cell to $D$ Cell. The existing $D$ Cell equipment would be used to treat the wastewater. After treatment the liquid would be routed to the LLV for staging. This option very much resembles the HLV deactivation process that was successfully performed in 1995 . In order to implement this option, existing pipe jumpers would have to remain or new pipe jumpers be installed in the airlock pipe trench. These pipe jumpers would allow routing of wastewater from all areas of the building to a tank located in $\mathrm{B}$ Cell for collection. Wastewater would then be transferred via a new pump to $\mathrm{D}$ Cell. This option is also very dependent on $\mathrm{B}$ Cell availability since work is required within the cell that cannot begin until equipment and dispersible removal has been completed. Any delay in the B Cell cleanout schedule would impact this option. It does however lend itself to the reuse of $\mathrm{D}$ Cell equipment with only minor anticipated maintenance to restore the equipment to an operational condition. Other advantages are the shielding provided by $\mathrm{B}$ Cell and D Cell and good manipulator coverage in D Cell. This would only allow for a relatively small amount of staging for the wastewater prior to treatment and would be more of a continuous operation. These disadvantages do not preclude this option from implementation but makes it less attractive than other options.

Option 2. (Figure 2) HLV Collection, Airlock Treatment and LLV Staging: This option would place the D Cell equipment or a new vendor supplied treatment skid in the airlock. The wastewater would be collected in the HLV and stored until treatment. The wastewater would then be transferred via the pipe trench to the treatment skid and transferred back to the LLV after treatment. This option requires no new tanks, little piping modifications and if acceptable decontamination of the $\mathrm{D}$ Cell equipment can be achieved, then reuse of the $\mathrm{D}$ Cell equipment is possible. Minor maintenance of the $\mathrm{D}$ Cell equipment could be made easier if work was completed by "hand" instead of manipulator. Utilizing the HLV as collection provides the most comprehensive collection system than any other option. The disadvantages for this option involve the airlock. The lighting and manipulator coverage in the airlock is poor and because the airlock is central to all REC operations and no extra space is available, this option would impact all other REC deactivation operations.

Option 3. (Figure 3) HLV Collection, LLV Treatment and LLV Staging: This option would consist of removing 1 or more of the LLV tanks, installing a treatment skid in the vault, pipe modifications within the vault and the collection of the wastewater in the remaining LLV tank(s). This option eliminates the need to maintain most of the pipe trench piping for liquid transfers. This option has many obstacles to overcome. The LLV is considered a very high-radiation area. 
This area would have to be considerably decontaminated or radioactive sources removed to allow removal of the tank(s) to provide room for the skid. When decontamination of the LLV has been completed the potential exists that "shine" from the adjacent HLV could cause the area to remain a high to very high radiation area thus eliminating manned access. Tank removal and piping modifications would then have to be done remotely. The equipment does not currently exist in the building to support remote operations of this kind. The change-out of filters and ion exchange columns would require similar remote operations or be sized sufficiently large to contain the entire curie burden. This would make the vessels nearly impossible to remove and send for storage or disposal because of the radiation fields that would be generated. These disadvantages make this option one of the least desirable.

Option 4. (Figure 4) HLV Collection, C Cell Treatment and LLV Staging: This option would require the installation of a treatment skid into $\mathrm{C} \mathrm{Cell} \mathrm{and} \mathrm{piping} \mathrm{modifications} \mathrm{associated} \mathrm{with}$ routing liquid from the pipe trench to the cell and from the cell wall to the skid.

Decontamination and maintenance of the D Cell equipment would be required. Using the HLV as collection provides the most comprehensive collection system than any other option. C Cell is clean and is equipped with two manipulator stations and windows. Access to $\mathrm{C}$ cell is good with a large door ( $6 \mathrm{ft}$ wide by $8 \mathrm{ft} \mathrm{high}$ ) and an pass through (18 in by 18 in) that could allow spent filters and ion exchange column change-out. By placing the equipment in $\mathrm{C} C$ Cell no pumping would be required as is the case with $\mathrm{D}$ Cell. One of the few disadvantages is that $\mathrm{C}$ Cell is not accessible by the Airlock crane but has a crane of its own. This does not eliminate the ability to move the treatment equipment into $\mathrm{C}$ Cell.

Option 5. (Figure 5) HLV Collection, D Cell Treatment and LLV Staging: This is a combination of options 1 and 4 . This would require establishing two routes for the wastewater from the pipe trench to $D$ Cell. In the past this route has been established through $B$ Cell, a new routing would have to be established that does not require B Cell interface. This would require the addition of a receiving sump and pump in the pipe trench. With current radiation field strengths this would be difficult. Using the HLV as collection provides the most comprehensive collection system than any other option. The option also lends itself well to the reuse of the D Cell equipment. Minor maintenance is anticipated to restore the D Cell equipment to and operational condition.

Option 6. (Figure 6) LLV Collection, LOS Treatment and LOS Staging: This option would require the installation of a new vendor supplied treatment skid (See assumption 6), staging tank and associated piping within the LOS. Not using the HLV for collection would eliminate the need to reopen discussions with the regulators in regards to the use of the HLV. Another advantage is that the equipment (tank and treatment skid) would be designed and built for the specific purpose. The disadvantages are that the piping for LLV collection is not as comprehensive as the HLV and the costs would be higher for a new skid, tank and associated piping.

Option 7. (Figure 7) HLV Collection, LOS Treatment, LLV Staging: This option would require a new vendor supplied treatment skid and little to no other plant modifications. Using the HLV as collection provides the most comprehensive collection system than any other option. Piping 
exists from the HLV to the LOS and from the LOS to LLV. The LOS shielding may not be adequate (2-4"lead) for worker protection from treatment unit but additional shielding could be easily added to the treatment unit. The LOS has good access and manipulators coverage. The only disadvantage is the need to purchase a new treatment skid (See Assumption 6). The reasoning behind this is that it is expected that the existing unit in D Cell can not be decontaminated to a level acceptable to remove from the REC. This option also would have the least impact on REC operations. It would allow total decontamination of the REC Complex without the need to remove, relocate or decontaminate this equipment until all wastewater was processed. 
HNF-3133, Rev. 0

Figure 1. Process Flow Diagram, 324 Building LWH, Option 1.

B Cell Collection D Cell Treatment

LLV Staging

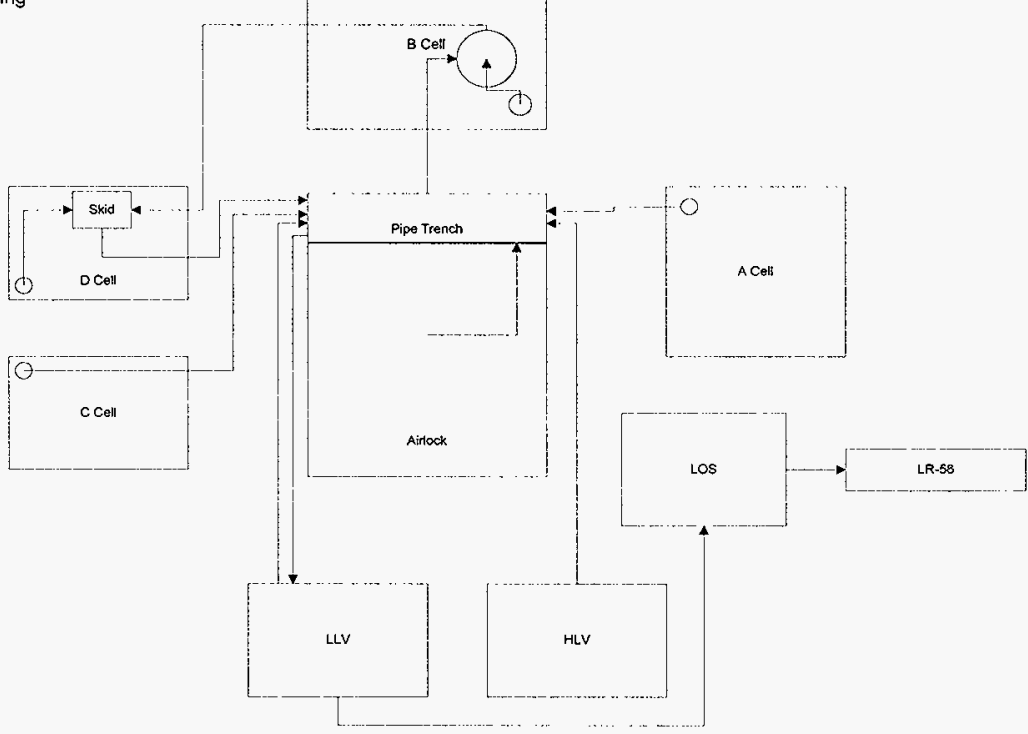


HNF-3133, Rev. 0

Figure 1. Process Flow Diagram, 324 Building LWH, Option 2.

HLV Collection

Airlock Treatment

LLV Staging

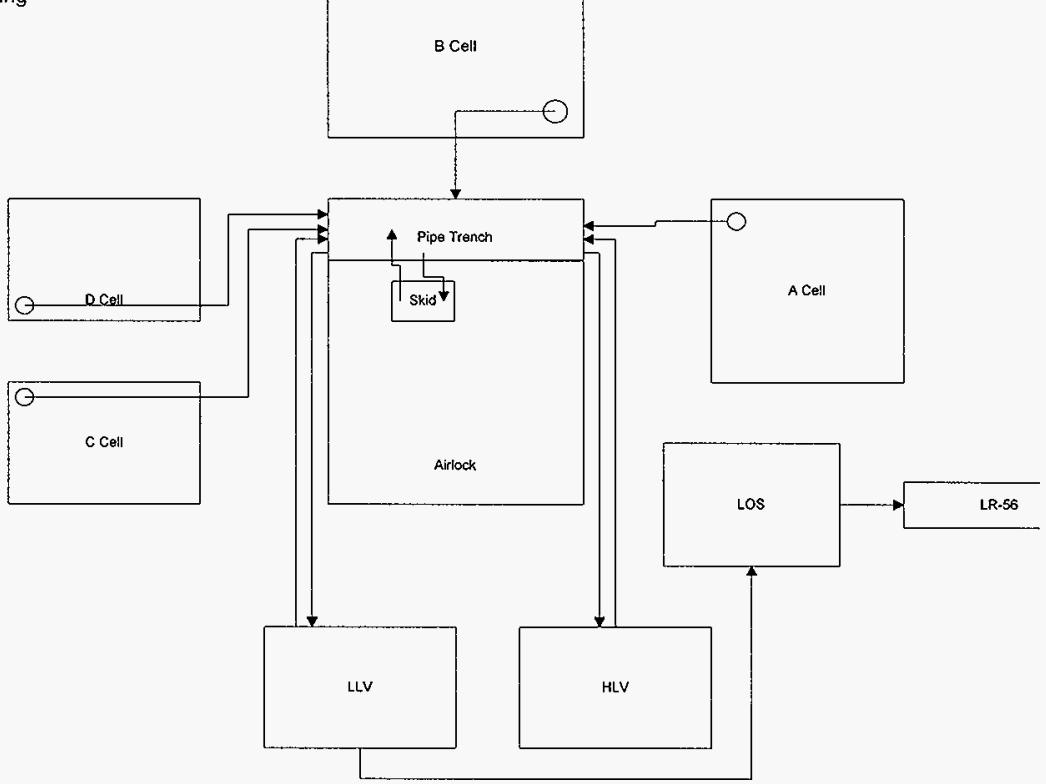


HNF-3133, Rev. 0

Figure 2. Process Flow Diagram, 324 Building LWH, Option 3.

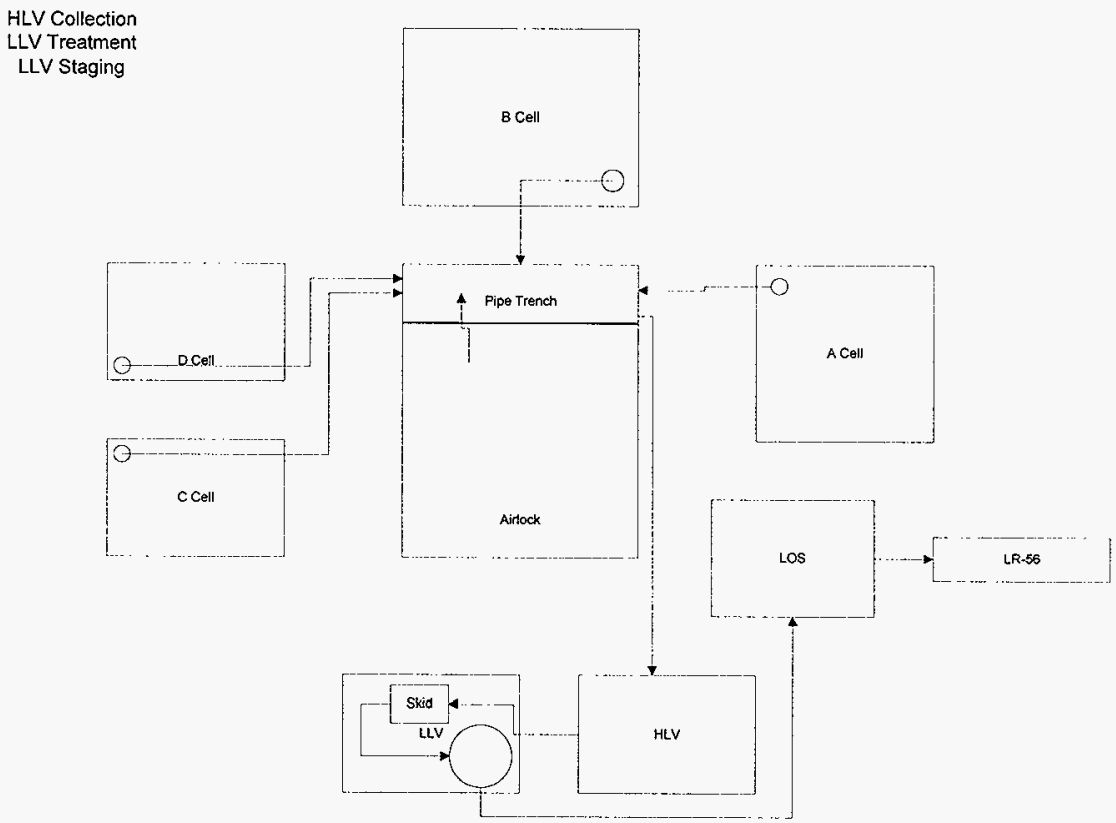


HNF-3133, Rev. 0

Figure 4. Process Flow Diagram, 324 Building LWH, Option 5.

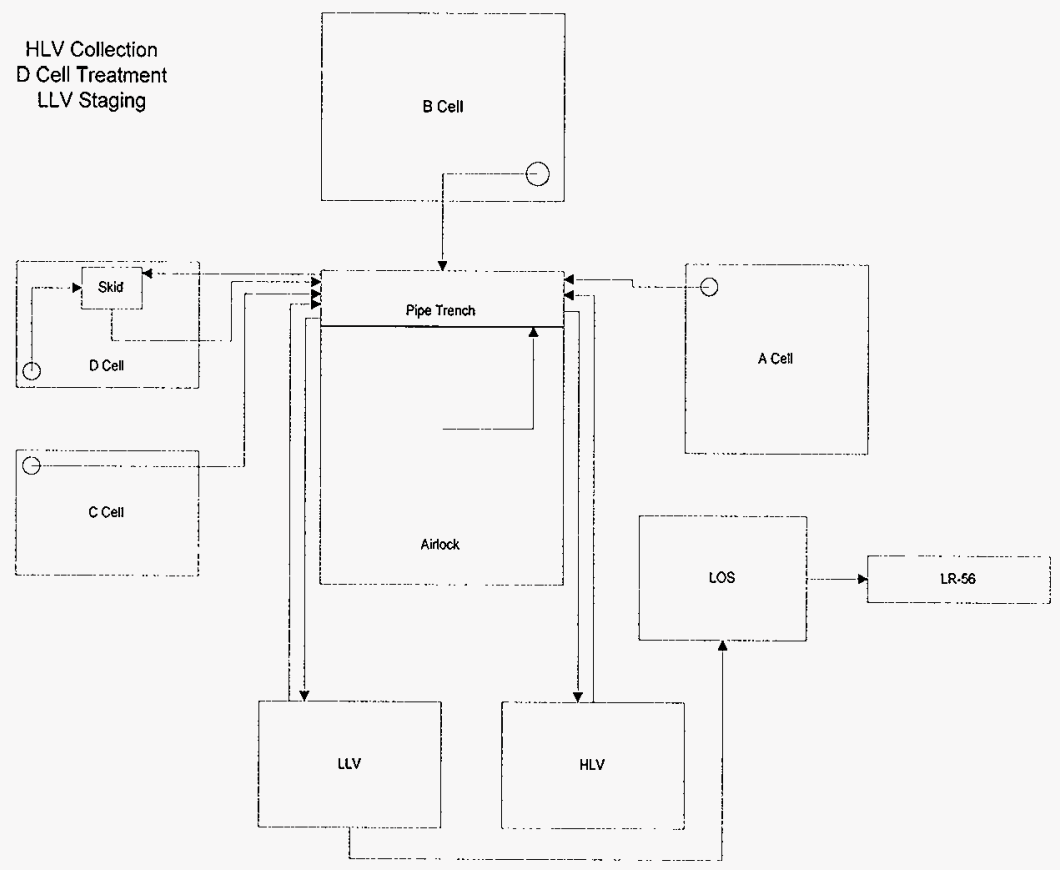


HNF-3133, Rev. 0

Figure 3. Process Flow Diagram, 324 Building LWH, Option 4.

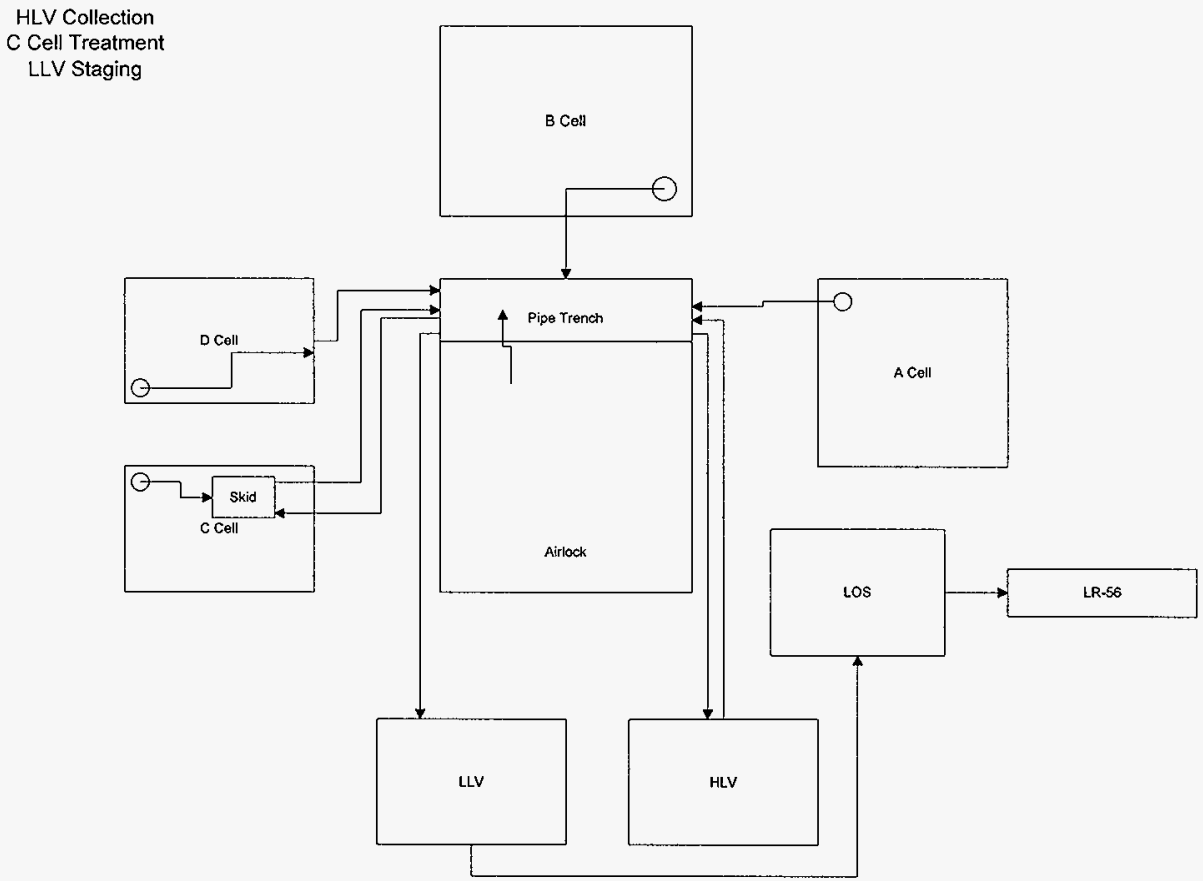


HNF-3133, Rev. 0

Figure 4. Process Flow Diagram, 324 Building LWH, Option 5.

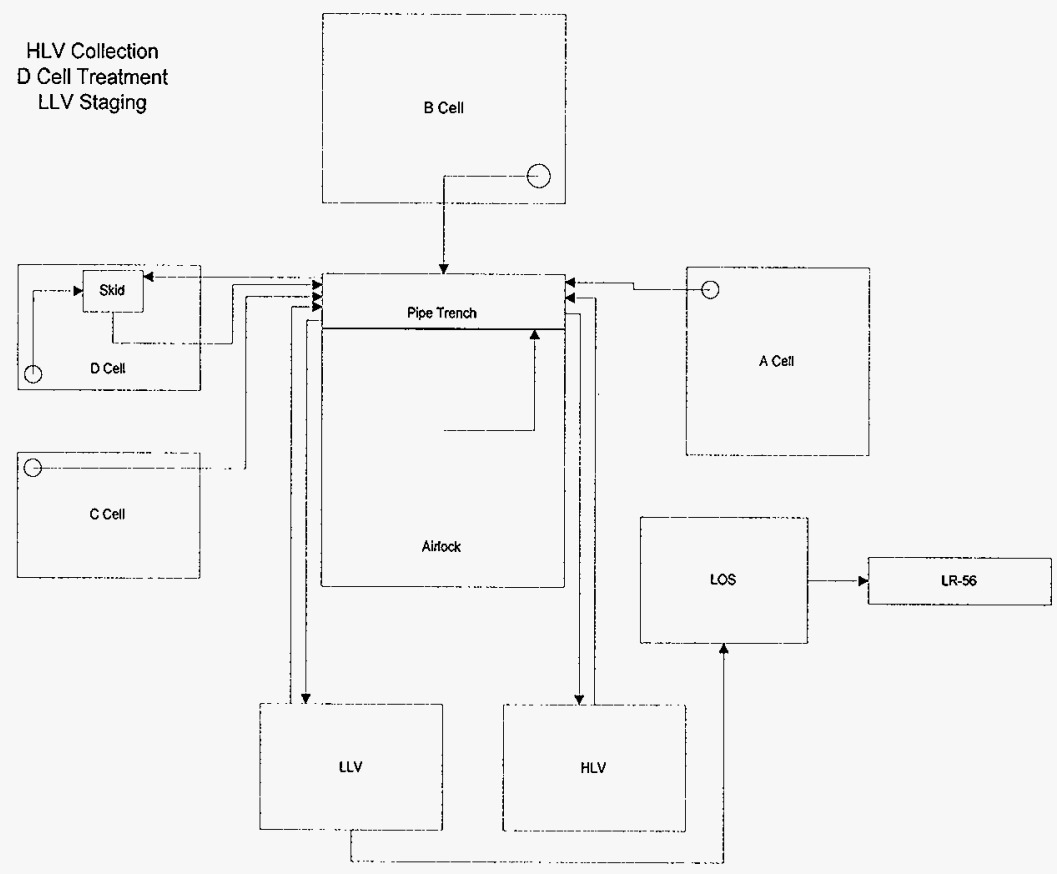


HNF-3133, Rev. 0

Figure 5. Process Flow Diagram, 324 Building LWH, Option 6.

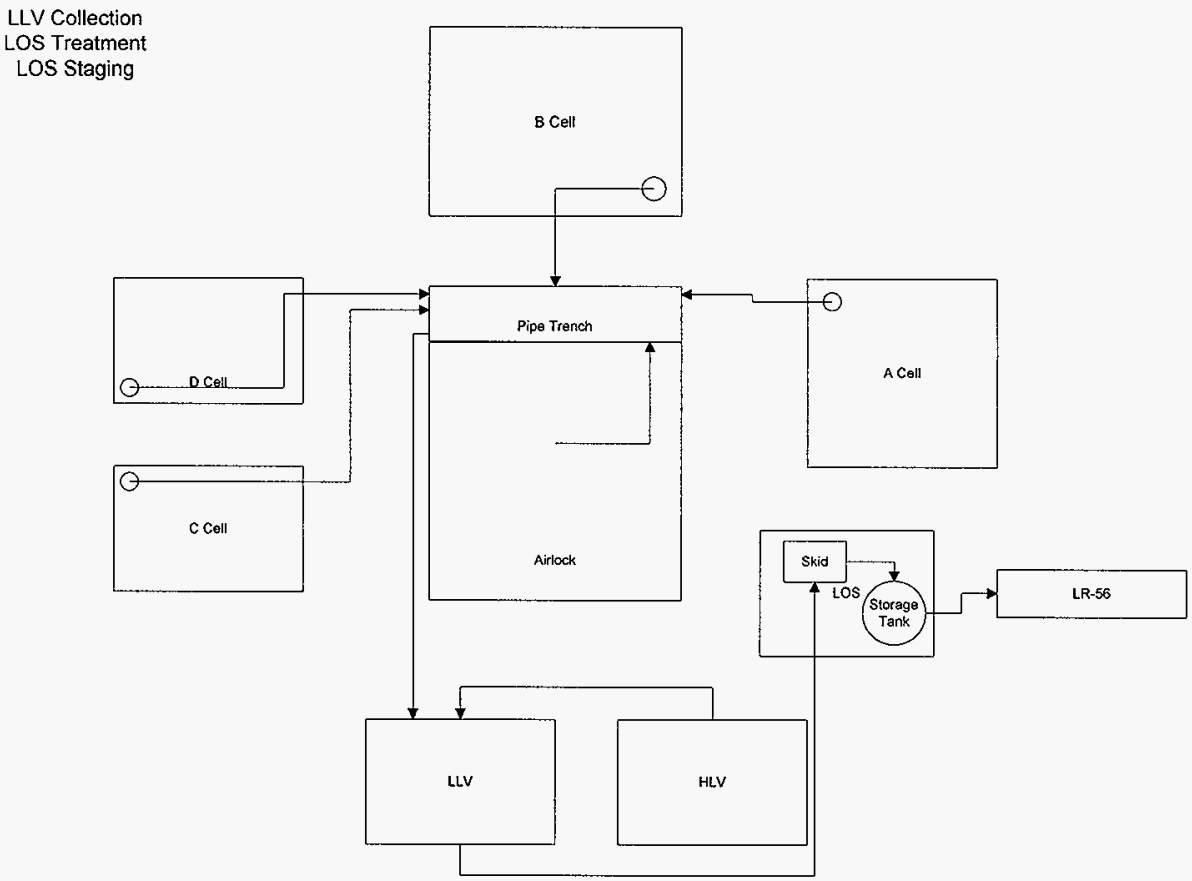


HNF-3133, Rev. 0

Figure 7. Process Flow Diagram, 324 Building LWH, Option 7.

HLV Collection LOS Treatment

LLV Staging

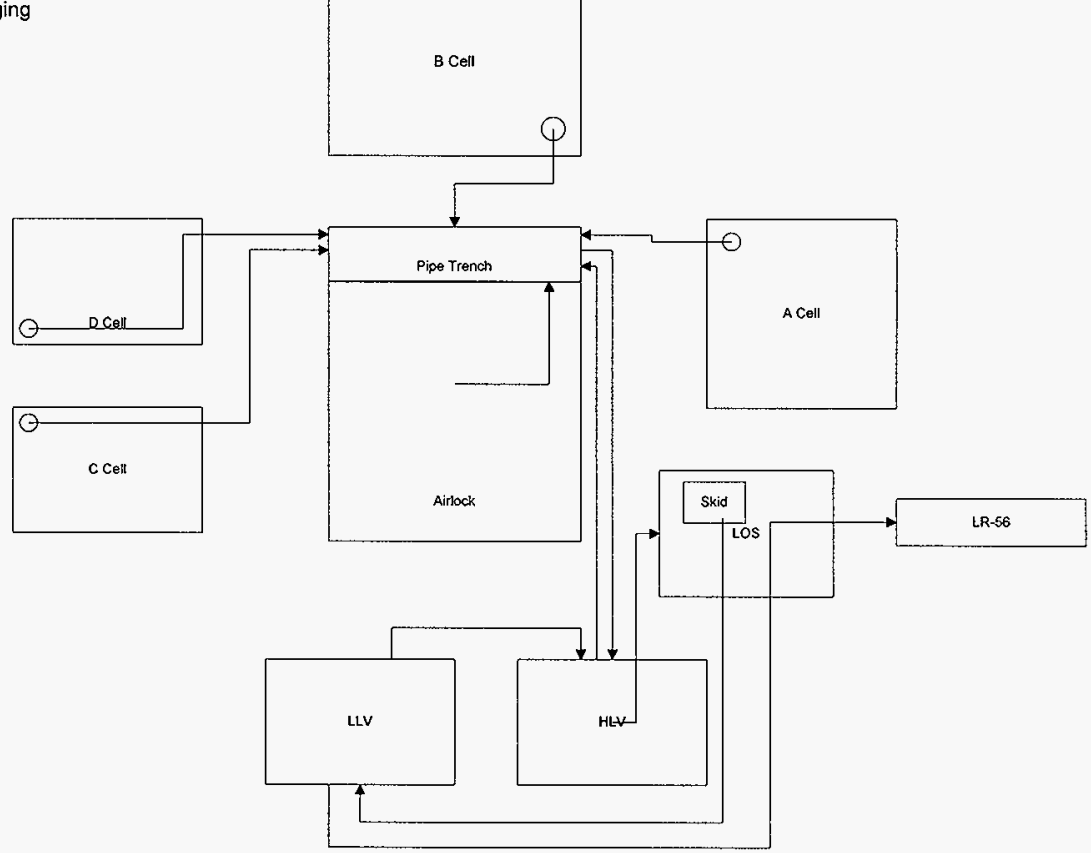




\subsection{Alternative Analysis}

Two previous studies (Parsons 1997 and Hobart 1997) have identified and evaluated several possible alternatives for the disposition of RLW from the 324 Building. These studies evaluated several combinations of whether to treat the wastewater and that treatment/storage facility could be used, the 200 Area Tank Farms, 300 Area TEDF or the 200 Area ETF. The conclusion from these studies recommended initial treatment of the wastewater in the 324 Building to a level that would allow disposal at either the 200 Area Tank Farms or the 200 Area ETF. The wastewater would be transferred via the LR-56 truck tanker to treatment/storage depending on characterization and acceptance criteria. What these studies did not evaluate was the options of collection, treatment and storage of wastewater within the building prior to load-out. The previous section provides a discussion of these options and the advantages and disadvantages of each.

\subsubsection{Weighing of Selection Criteria}

The selection criteria were weighted according to their degree of importance in determining the effectiveness of the options and were assigned numerical values. The performance of each option was estimated with respect to each criterion in the subsequent state of the selection process in this report. The performance level was judged as below average, average or above average with a corresponding score of 1,2 , or 3 , respectively. The weighted score is the product of each weighted criterion and the corresponding performance level score. The total score of each option is the summation of these products. The specific criterion weight for each selected option was derived from discussion among personnel involved in the study. The corresponding weight factors are shown in Table 7.

\subsection{Selection Criteria}

It was determined that seven basic criteria separated all the options. The criteria evaluated were: shielding, applicability of existing piping, access to the area, manipulator availability and coverage, interferences with other programs and equipment, tank capacity, and presence of existing equipment. Table 7 provides the detailed evaluation. A description of each criteria follows.

Shielding evaluated the amount of shielding present to protect workers during all phases of the system. It includes collection and storage, treatment and staging prior to load-out. This category was given the highest weight factor due to worker safety. REC hot cells and the vaults were give the highest possible rating and other areas received correspondingly lower ratings.

Piping was evaluated to determine how much of the existing piping could be used and how much would require rework and jumpers. Using the high-level and low-level vault system for collection, storage and staging was rated with the highest score.

Access refers to the ability to physicaliy or remotely enter the area. This evaluated the existence and size of doors, the ability to install, remove, repair and/or replace equipment and the existence of cranes. 
Manipulators evaluated the existence and the degree of manipulator coverage.

Interferences refers to the impact that placing equipment or using an area would have on other activities. The B Cell Project was rated as the number one interference to be avoided and the ratings were based on impact to that project.

Tank Capacity considered the storage volume of existing tanks. Added tanks were subsequently given a lower value, however, being able to size a new tank to fit a specific need was also given consideration.

Equipment refers to the existing equipment in the plant. Use of the D Cell treatment skid received the highest rating. However, because of the unknown condition and durability of the $D$ Cell equipment this criteria was given the lowest weight factor. 
HNF-3133, Rev. 0

Table 6. Weighting of Selection Criteria.

\begin{tabular}{|c|c|c|c|c|c|c|c|c|c|c|c|c|c|c|c|}
\hline \multirow[b]{2}{*}{ 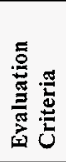 } & \multirow[b]{2}{*}{$\begin{array}{l}\overrightarrow{5} \\
\overrightarrow{5} \\
3\end{array}$} & \multicolumn{2}{|c|}{ Option 1} & \multicolumn{2}{|c|}{ Option 2} & \multicolumn{2}{|c|}{ Option 3} & \multicolumn{2}{|c|}{ Option 4} & \multicolumn{2}{|c|}{ Option 5} & \multicolumn{2}{|c|}{ Option 6} & \multicolumn{2}{|c|}{ Option 7} \\
\hline & & $\begin{array}{l}\stackrel{D}{\circ} \\
\stackrel{\circ}{\circ}\end{array}$ & 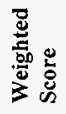 & 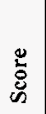 & 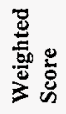 & 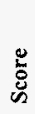 & 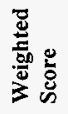 & 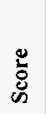 & 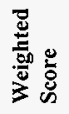 & 莒 & 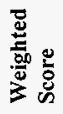 & $\begin{array}{l}0 \\
\stackrel{0}{\circ} \\
\ddot{n}\end{array}$ & 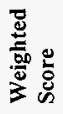 & 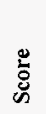 & 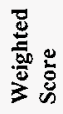 \\
\hline 苞 & 0.25 & 3 & 0.75 & 2 & 0.5 & 3 & 0.75 & 3 & 0.75 & 3 & 0.75 & 2 & 0.5 & 3 & 0.5 \\
\hline م: & 0.1 & 1 & 0.1 & 2 & 0.2 & 1 & 0.1 & 2 & 0.2 & 1 & 0.1 & 3 & 0.3 & 3 & 0.3 \\
\hline 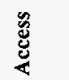 & 0.2 & 1 & 0.2 & 3 & 0.6 & 1 & 0.2 & 3 & 0.6 & 3 & 0.6 & 3 & 0.6 & 3 & 0.6 \\
\hline 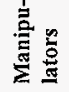 & 0.1 & 3 & 0.3 & 1 & 0.1 & 1 & 0.1 & 3 & 0.3 & 3 & 0.3 & 3 & 0.3 & 3 & 0.3 \\
\hline 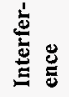 & 0.2 & 1 & 0.2 & 1 & 0.2 & 2 & 0.4 & 2 & 0.4 & 2 & 0.4 & 3 & 0.6 & 3 & 0.6 \\
\hline 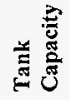 & 0.1 & 1 & 0.1 & 3 & 0.3 & 2 & 0.2 & 3 & 0.3 & 3 & 0.3 & 1 & 0.1 & 3 & 0.3 \\
\hline 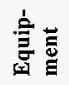 & 0.05 & 3 & 0.15 & 2 & 0.1 & 1 & 0.05 & 2 & 0.1 & 3 & 0.15 & 1 & 0.05 & 1 & 0.05 \\
\hline Total & 1.0 & 13 & 1.8 & 14 & 2.0 & 11 & 1.8 & 19 & 2.65 & 18 & 2.6 & 17 & 2.45 & 18 & 2.9 \\
\hline
\end{tabular}




\subsection{Preferred Alternative}

From Table 7 ,Option 7 stands out as the preferred option. The advantages that make this option most preferred is that almost no new piping is required for this option and treatment in the LOS does not interfere with REC operations. The only disadvantage is that the shielding in the LOS is not as good as in the REC cells, but the dose can easily be mitigated by minor lead shielding on the treatment unit that concentrate the waste (i.e. filters and ion exchange columns).

Using the HLV for collection provides the most comprehensive piping system for the collection of the wastewater. The vault provides the necessary shielding for worker protection and adequate storage to effect batch processing of the wastewater.

Locating the treatment system in the LOS allows for the transfer of liquid to and from the LLV and HLV with only tie-in of the treatment system required, Steam jets also exist to transfer the wastewater.

Using the LLV for storage prior to load-out allows for batch load-out operations of multiple loads to maximize operational efficiency. Sampling and chemical addition to allow acceptance also exists. 


\subsection{CONCEPTUAL DESIGN}

\subsection{Project Scope}

As described in Section 6, the selected alternative, HLV collection, LOS treatment, LLV staging, and exterior truck load-out station, will maximize the use of existing piping, tanks and equipment to the extent possible. Following paragraphs describe the needed plant modifications to implement this approach. Attachment 3 provides a conceptual design of the load-out facility.

\subsection{Piping}

Minor piping modifications will be required to support this option. An extensive collection system between the REC and the HLV exists and will be used. The only potential piping modifications exist in the REC Airlock Pipe Trench. During the pipe trench clean-out it may be necessary to remove all piping. This could require new pipe jumpers from the cells to the HLV. This would require a minimum of four new jumpers to be fabricated. Piping between both the LLV and HLV and the LOS exists and would not be affected by the pipe trench clean-out, so no new piping would be required. Piping for the addition of the SMF deactivation wastewater to the LLV for load-out will be provided by SMF deactivation and is not part of this scope.

A total of six new jumpers will be estimated for this effort.

Piping tie-ins to the plant water and air systems will be made at a convenient location near the truck door. The piping will be extended to the load-out platform.

\subsection{Load-Out Stall Modifications}

Minor modifications in the LOS will be made to enable the tie-in of the treatment system and load out piping. A booster pump and small in-line tank will be installed to lift the wastewater to the load out platform. The pump will deliver $25 \mathrm{gpm}$ to the tank trailer. Valves will be installed to regulate wastewater supply from the jet system and to the tanker. Removal of the "bowling ball casks" stored in the LOS, decontamination of the area, relamping of the lights and repairs to the existing manipulators will be required prior to setting up the treatment system.

\subsection{Low-Level Vault}

No modifications are anticipated for the LLV. It is assumed that deactivation of the LLV will be initiated after major deactivation activities within the REC Complex have been completed. A one-time flush and rinse prior to introduction of the treated wastewater may be required to maintain acceptance levels of the wastewater.

\subsection{High-Level Vault}

No modifications are anticipated for the HLV. It is assumed that deactivation of the HLV will be initiated after major deactivation activities within the REC Complex have been completed. 
HNF-3133, Rev. 0

\subsection{Treatment Skid Maintenance/Modifications}

This option requires the procurement or design and build of a new treatment skid equipped with remote monitor and control system. It is anticipated that the new unit would be substantially similar to the current $\mathrm{D}$ Cell equipment. The strategy is to issue a specification for a vendor supplied skid. In order to do this characterization of the wastewater generated during deactivation must be developed.

\subsection{Load-Out Station Modifications}

The 324 Building truck bay is not physically large enough to contain the proposed tankers that are currently available on the site. Modification to the building structure for this effort is not feasible. It is assumed that because $100 \%$ of the piping can be visually inspected and that the piping will be welded stainless-steel, no double contained piping will be required. It has also been assumed that because of the nature of the LR-56 tanker no secondary containment will be necessary for the truck trailer.

The load-out station will consist of an elevated platform on the northeast corner of the 324 Building, immediately adjacent to the CHA truck door (see attached sketch). Treated wastewater will be transferred by 1.5-in. stainless-steel welded piping from the LOS to the loadout platform. The platform will be equipped with valving, pump control (start/stop), monitor and control station, a swing arm with a Zenith ${ }^{\mathrm{TM}}$ connector to mate with the tanker fill flange, service air and water.

Air and water services will allow for the flushing, draining and drying of the exterior piping to avoid contamination build up and freeze damage.

\subsection{Electrical}

Electrical services will be required for the treatment system, load-out pump and control. The services will be extended from existing plant services at the nearest convenient location.

\subsection{Testing}

After the modifications are complete, testing of the piping modifications, treatment system and load-out station will be required. Operations personnel will prepare operating procedures and provide start-up and testing support. The ATP will be prepared in conjunction with the design. 


\subsection{PERMITTING AND DOCUMENTATION}

The 324 Building is currently classified as a non-permitted TSD under RCRA. Compliance to RCRA requirements only apply to the building as a generator. A letter (95-PCA-312) provides the basis for the allowable treatment methods by generator under the Hanford Facility Dangerous Waste Permit. As part of an agreement with the regulators, TPA milestones were established for the closure and deactivation of the building. A Deactivation Plan and a Closure Plan have been written for the building. Each plan covers discrete areas of the building and how that area will be closed or deactivated. It is assumed that the wastewater created during the deactivation activities are a dangerous waste under Washington State Administrative Codes WAC 173-303. The 324 Building is permitted under the Nation Emission Standards for Hazardous Air Pollutants (NESHAPs) program and is considered a major stack.

\subsection{National Environmental Policy Act}

It is assumed that this effort will be performed under a NEPA Categorical Exclusion (CX). It is anticipated that no other NEPA documentation will be required.

\subsection{Air Permitting}

The 324 Building has a major stack under NESHAPS. Several Notices of Construction (NOC) exist for the building. An NOC will be prepared for this effort. NOC's for the deactivation activities may be required and will be prepared as information becomes available but are not included as part of this project.

\subsection{Safety Documentation}

All facility modifications require an Unreviewed Safety Question (USQ) evaluation. If determined by the USQ evaluation that modification to the safety basis is required an addendum to the SAR will be completed. It is assumed that this effort will not require modifications of or to the safety basis or documentation.

\subsection{Quality Assurance}

Project-specific quality assurance requirements will be described in a PMP developed for these modifications. The governing Quality Assurance Program Plans will be used to develop these requirements. The quality requirements will be defined during detailed design and use a graded approach for setting Quality Assurance (QA) approval levels. The conceptual estimate for construction is based on industrial codes and standards. No safety class equipment or components are anticipated for this effort. 
HNF-3133, Rev. 0

\subsection{REFERENCES}

BWHC 1997, 300 Area Waste Option Study, B\&W Hanford Company, Richland Washington

Parsons 1997a, Modifications to Radioactive Liquid Waste Handling Systems for 324 and 327

Facilities, Parsons Infrastructure and Technology Group, Inc., Richland, Washington.

HNF-IP-1000, Waste Acceptance Criteria for the 300 Area Process Sewer and Treated Effluent Disposal Facility, B\&W Hanford Corporation, Richland, Washington.

WMH 1997, LERF/ETF Treatability Envelope, Waste Management Federal Services of Hanford, Richland, Washington

WHC-SD-WM-EV-053, Double-Shell Tank Waste Analysis Plan, Westinghouse Hanford Company, Richland, Washington.

HNF-IP-1289, 324/327 Buildings Stabilization/Deactivation Project Management Plan, B\&W Hanford Company, Richland, Washington.

95-PCA-312, Letter, J.E. Rasmussen, DOE to C. Silva, Ecology, Notification of Dangerous Waste Activities, Form 2, Revision 1, for the Hanford Facility (WA7890008967), dated $5 / 25 / 95$. 
HNF-3133, Rev. 0

\section{Attachment 1}

\section{Building RLWS}




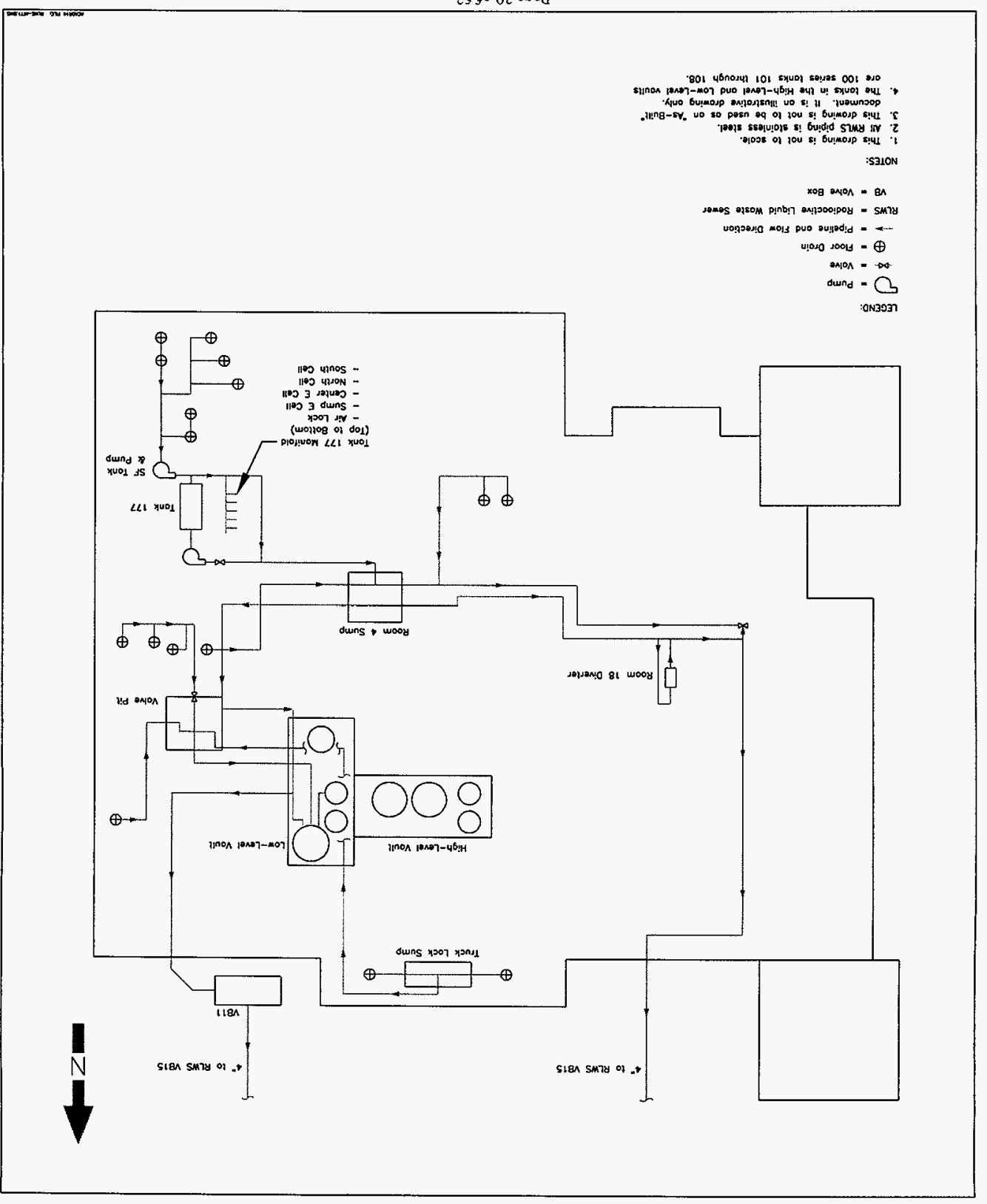

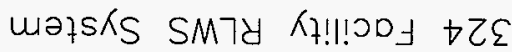

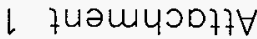

$0 \cdot \wedge \partial y$ ' $\varepsilon \varepsilon[\varepsilon-\rfloor N H$ 
HNF-3133, Rev. 0

Attachment 2

\section{Building REC Piping Flow Diagram}




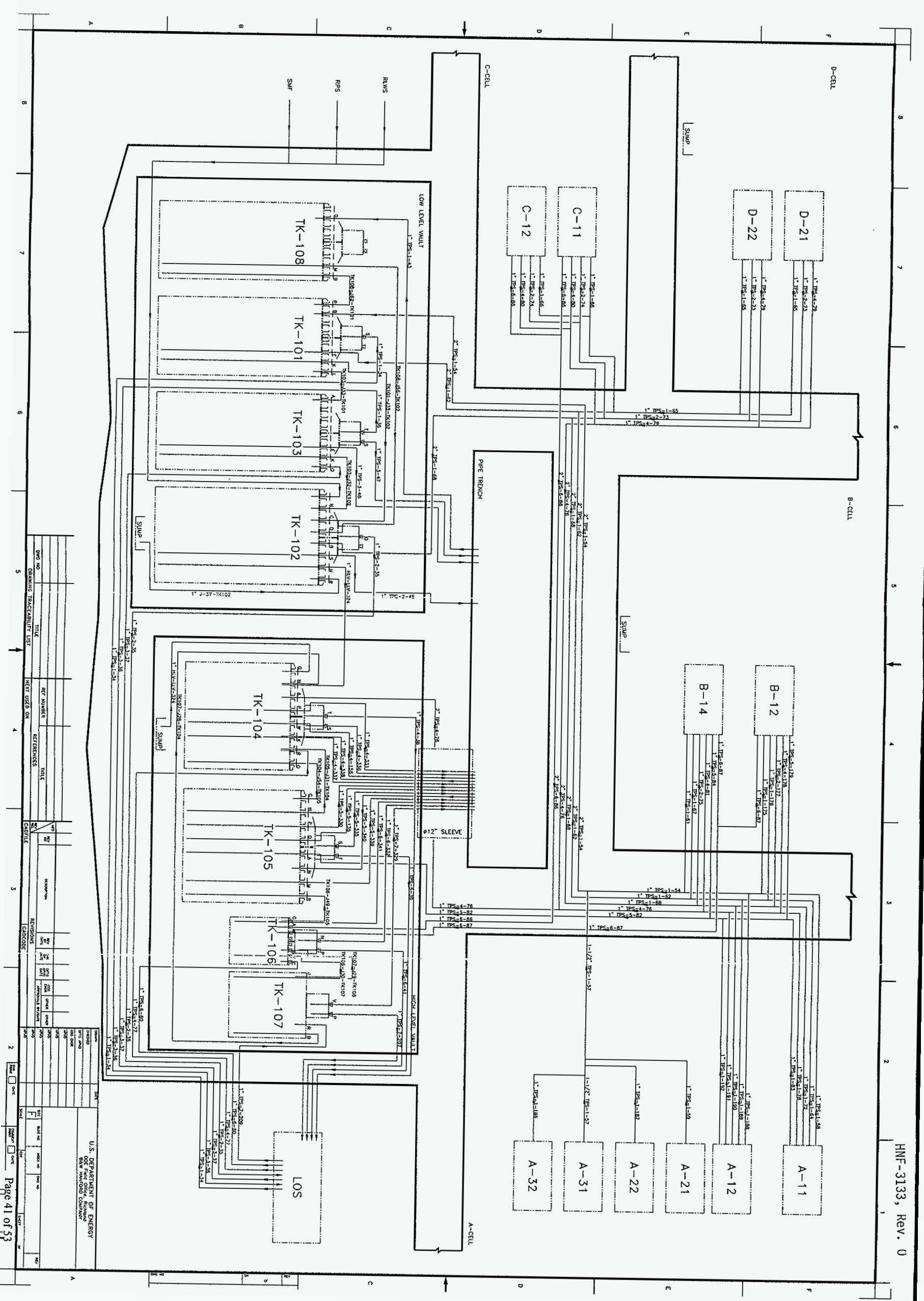


HNF-3133, Rev. 0

Attachment 3

324 Liquid Waste Handling and Removal System Conceptual Design 
HNF-3133, Rev. 0

II

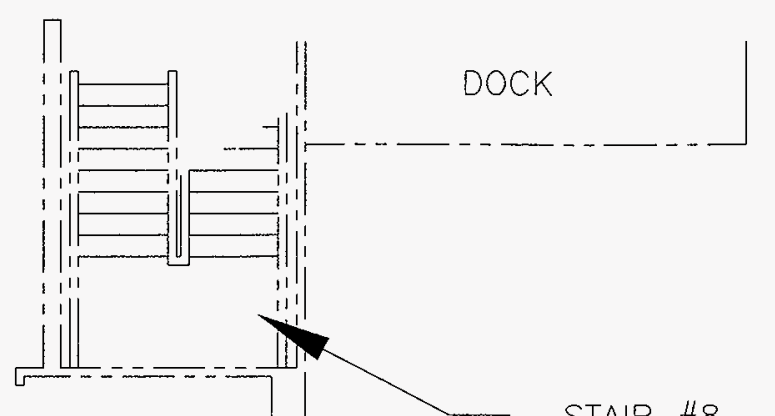

\begin{tabular}{|c|c|c|c|}
\hline \multicolumn{4}{|c|}{ PARTS/MATERIAL LIST } \\
\hline QTYQOTY & ITEM & DESCRIPIIEN & REFERENCE \\
\hline 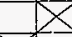 & & ARRANGEMENT & \\
\hline 1 & 2 & 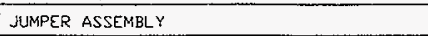 & \\
\hline 1 & 3 & GATT ACCESS PLATFORM W/ FOLDING GANGWAY & \\
\hline$i$ & 4 & Loo GaLlan TANK (2' DIA $\times 4^{\prime}$ HIGH) & \\
\hline 1 & 5 & 1 H.P. CENTRIGUAL PUMP & \\
\hline$i$ & 6 & LEVEL TRANSMETTER & \\
\hline 1 & 7 & FLOW TRANSMITTER & \\
\hline 1 & 8 & VALVE, $2^{*}$ GaTe, 150\# FLanged & \\
\hline 1 & 9 & VALVE, 1-1/2' GATE, 150H FLANGED & \\
\hline 1 & 10 & VALVE, L-1/2' CMECK, 150\# FLANGED & \\
\hline 1 & 11 & FLANGE, $2^{\prime}$ RFWN & \\
\hline s & 12 & ELBOW, $1-1 / \mathrm{C}^{*}$ 90 DEGREE & \\
\hline 2 & 13 & REDUCING TEE $1-1 / 2^{\circ} \times 1^{\prime}$ & \\
\hline 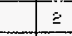 & 14 & Valve, 1* Gate, 150H flanged & \\
\hline ¿ & 15 & BACKFLOW PREVENTOR, $1{ }^{\circ}$ 150\# FLANGED & \\
\hline 1 & 16 & SWING ARM SUPPORT/NGZZLE GUIDE & \\
\hline 2 & 17 & CONTREL PANEL & \\
\hline 2 & 18 & UNISTRUT MOUNI ING HARDWARE & \\
\hline 2 & 18 & FLANGE, $2^{*}$ SLIP-DN & \\
\hline$\therefore$ & 20 & FLANGE, $1-1 / 2^{*}$ SLLP-ON & \\
\hline$A B$ & 21 & PIPE, $1-1 / 2^{*}$ SCHEDULE 40 & \\
\hline AR & 22 & PIPE, I' SCHEDULE 40 & \\
\hline$\underline{\underline{2}}$ & 23 & LEVEL INDICATOR/ALARM & \\
\hline ? & 24 & FLOW TRANSMITIER/TOTAL IZER & \\
\hline
\end{tabular}

- TRANSFER TANK

PUMP \& PIPING

(SEE SHEET ?)

STAIR \#8

'A'
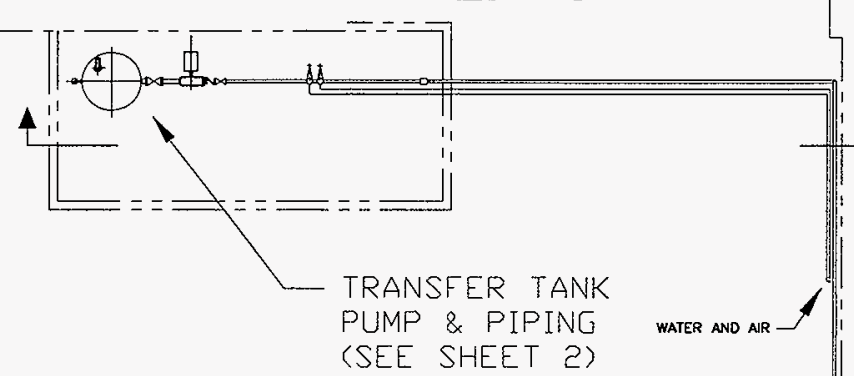

$4^{\prime} A^{\prime}$

1
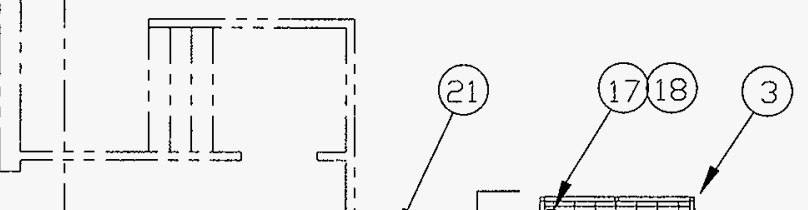

$2+-=-2=0$

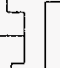

(2)
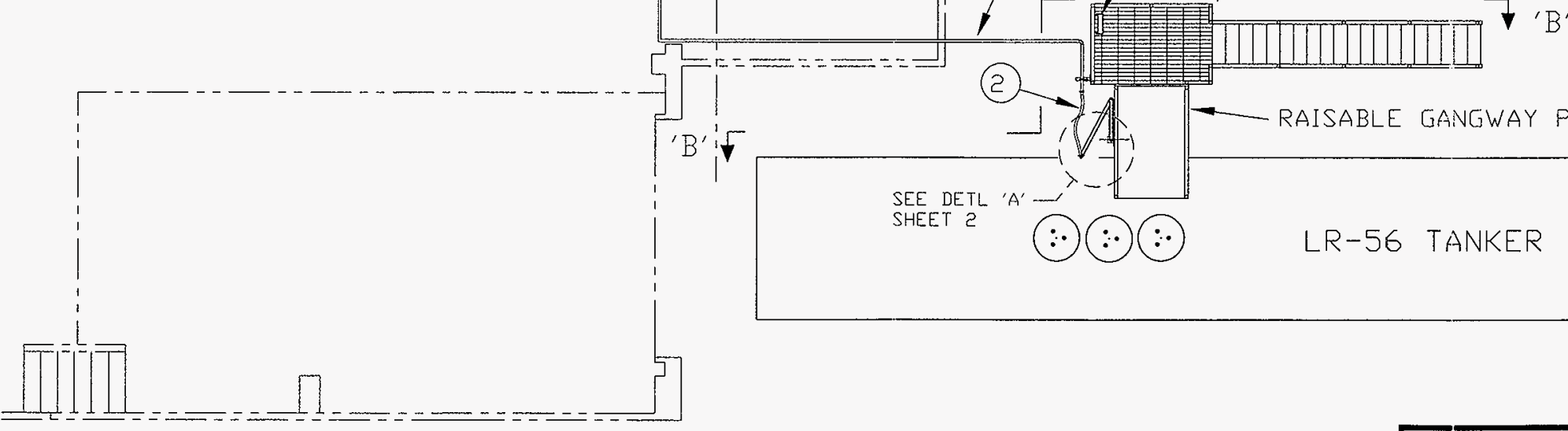

$3^{\prime}$

SEE DETL 'A'

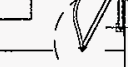

- raisable gangway platform

SHEET

TANKER

CINCEPTUAL 324 FACILITY RLW TRANSFER SYSTEM

SHEET 1 of 3 


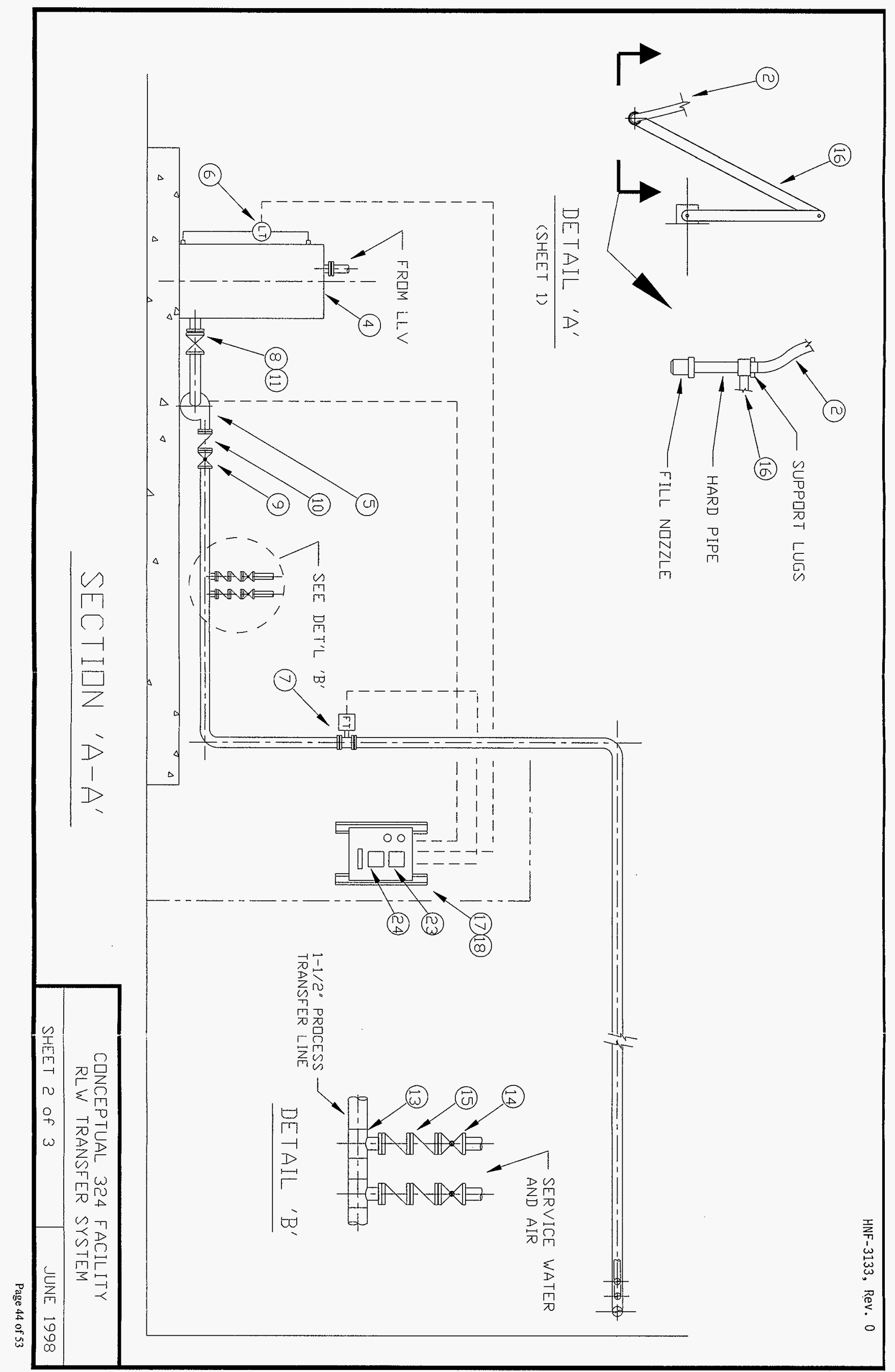




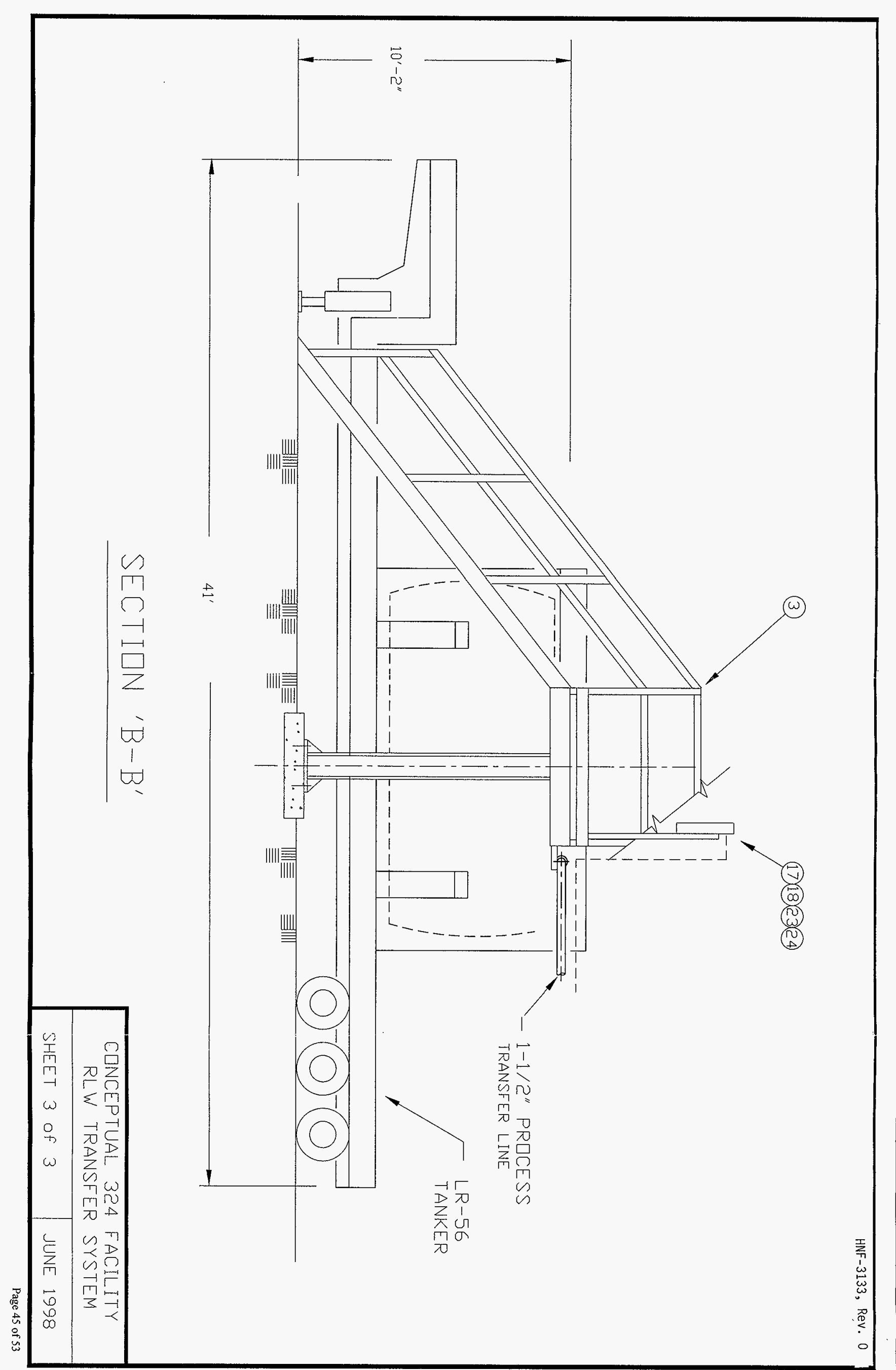


HNF-3133, Rev. 0

\section{Attachment 4}

\section{Conceptual Design Estimate}


HNF-3133, Rev. 0

\section{Facility Project Plan Conceptual Estimate}

Conceptual Estimate 324 Liquid Waste Handling and Removal Sysem

Design

Piping

SS piping

1 " SS Sched 40

$11 / 2^{*}$ SS Sched 40

1" SS Flex

Jumpers

Ss fittings

Flange 2" RFWN

Flange 2" Slip-on

Flange $11 / 2 "$ Slip on

LR Elbow $11 / 2^{\prime \prime}$

LR Elbow 1"

Reducing Tee

Mechnical Equipment

Centrifiga; Pump 1 H.P

Receiving Tank $100 \mathrm{gal}$

Level Transmitter

Level Indicator and Alarm

Flow Transmitter

Gate Valve 2"

Gate Valve $11 / 2^{\prime \prime}$

Gate Valve $1^{*}$

Check Vaive $11 / 2^{\prime \prime}$

Backflow Preventor

Globe Valve 1 1/2"

Globe Valve 1"

Unistrut

vendor Supplied Treatment Skıd

60,000 gallon@ 5 gpm output

Load Out Station

Platform and Stairs

Footings and Piers

Pipe Supports

Swing Arm Assembly

Solenoid Valves

Flow Element

Flow Totalizer

Control Panel

Electrical

Cabling

\#3 4 wire 130ft

\#6 4 wire $50 \mathrm{ft}$

$\# 104$ wire $100 \mathrm{ft}$

Conduit \& Fittings

$11 / 4^{\prime \prime}$ Rigid Conduit

3/4" Rigid Conduit

Elbow $11 / 4$

elbow $3 / 4$

Boxes

Breakers

Pump Starter

Diconnect

Distribuition Panel

Remote Control Station
$15 \%$ of Construction estimate

117474.85

$\begin{array}{lllll}\text { Units } & \text { Material } & \text { Material } & \text { Labor } & \text { Labor } \\ & \text { Unit Price } & \text { Total Price } & \text { Unit Price } & \text { Total Price }\end{array}$

$\begin{array}{rrrrr}100 & 700.00 & 805.00 & 78.30 & 234.90 \\ 160 & 1037.00 & 1908.08 & 91.35 & 274.05 \\ 20 & 400.00 & 400.00 & 200.00 & 600.00\end{array}$

$\begin{array}{lll}8000.00 & 2400.00 & 7200.00\end{array}$

$\begin{array}{rrrrr}1 & 431.00 & 431.00 & 73.08 & 219.24 \\ 2 & 165.00 & 330.00 & 36.54 & 219.24 \\ 7 & 150.00 & 1050.00 & 39.15 & 822.15 \\ 5 & 15.00 & 75.00 & 78.30 & 1174.50 \\ 6 & 12.00 & 72.00 & 73.08 & 1315.44 \\ 2 & 35.00 & 70.00 & 109.62 & 657.72\end{array}$

$\begin{array}{rrrrr}1 & 9137.00 & 9137.00 & 4177.68 & 12533.04 \\ 1 & 3000.00 & 3000.00 & 502.05 & 1506.15 \\ 1 & 875.00 & 875.00 & 73.66 & 220.98 \\ 1 & 809.00 & 809.00 & 195.75 & 587.25 \\ 1 & 685.00 & 685.00 & 73.66 & 220.98 \\ 1 & 1024.50 & 1024.50 & 48.29 & 144.87 \\ 1 & 849.00 & 849.00 & 45.68 & 137.04 \\ 2 & 575.25 & 1150.50 & 39.15 & 234.90 \\ 1 & 428.65 & 428.65 & 50.90 & 152.70 \\ 1 & 187.00 & 187.00 & 70.47 & 211.41 \\ 1 & 1048.00 & 1048.00 & 32.63 & 97.89 \\ 1 & 1048.00 & 1048.00 & 32.63 & 97.89 \\ 100 & 3.61 & 361.00 & 1868.50 & 5605.50\end{array}$

$\begin{array}{lllll}1 & 400000.00 & 400000.00 & 10400.00 & 31200.00\end{array}$

$\begin{array}{rrrr}11050.00 & 11050.00 & 2010.30 & 6030.90 \\ 159.00 & 636.00 & 172.00 & 2064.00 \\ 1330.00 & 13300.00 & 1494.80 & 4484.40 \\ 2500.00 & 2500.00 & 353.80 & 1061.40 \\ 1640.00 & 3280.00 & 62.64 & 375.84 \\ 295.00 & 295.00 & 78.30 & 234.90 \\ 215.00 & 215.00 & 113.50 & 340.50 \\ 1575.00 & 1575.00 & 634.00 & 1902.00\end{array}$

1575.00

634.00

1902.00

$\begin{array}{rrrrr}520 & 27.43 & 142.64 & 43.86 & 684.22 \\ 200 & 13.64 & 27.28 & 28.38 & 170.28 \\ 400 & 6.02 & 24.08 & 18.06 & 216.72 \\ & & & & \\ 200 & 151.32 & 302.64 & 110.94 & 665.64 \\ 200 & 82.35 & 164.70 & 110.94 & 665.64 \\ 20 & 7.18 & 143.60 & 5.16 & 309.60 \\ 20 & 3.76 & 75.20 & 3.87 & 232.20 \\ 6 & 0.72 & 4.32 & 3.87 & 69.66 \\ 6 & 181.00 & 1086.00 & 220.98 & 662.94 \\ 1 & 550.00 & 550.00 & 361.00 & 1083.00 \\ 1 & 1368.64 & 1368.64 & 258.00 & 774.00 \\ 1 & 722.00 & 722.00 & 634.00 & 1902.00 \\ 1 & 318.00 & 318.00 & 634.00 & 1902.00 \\ & & & & \\ & & 471523.83 & & 91499.68\end{array}$


HNF-3133, Rev. 0

\section{Facility Project Plan Conceptual Estimate}

MPR 7.0\%

Contigency $30 \%$

Total
33006.67

151359.15

655889.64
6404.98

29371.40

$127276.05 \quad 900640.54$

1 Estımated labor unit rate has been multiplied by three to account for radiation work and building operation interface

2 Hourly rate for facility personnel is $\$ 50 / \mathrm{hr}$ Bargaining unit, $\$ 60 / \mathrm{hr}$ Exempt, $\$ 35 / \mathrm{hr}$ non-exempt

3 Crew size consists of 4 bargaining units and 1 exempt

4 Treatment skid is assumed to require $110 \mathrm{v} 60 \mathrm{amp}$ service and $110 \mathrm{v} 15 \mathrm{amp}$ control power. 
HNF-3133, Rev. 0

\section{Attachment 5}

\section{Project Schedule}




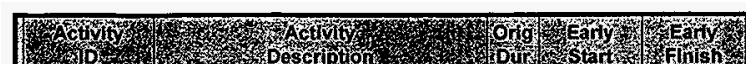

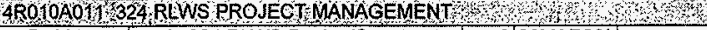
\begin{tabular}{|l|l|r|l|l|}
\hline $4 R R 4000$ & Begin 324 RLWS Design/Construct & 0 & 30MAR98* & \\
\hline 4RR4050 & Identify systems/components to be & 80 & 30 MAR98* & 22JUL98
\end{tabular} \begin{tabular}{|l|l|r|r|}
\hline 4RR4060 & Identify/obtain existing drawings & 80 & 30 MAR98* \\
\hline 22.JUL98
\end{tabular} \begin{tabular}{|l|l|l|l|l|l|}
\hline 4RR4070 & Eval system capabilities to meet & 268 & 30MAR98* 21APR99 \\
\hline
\end{tabular} \begin{tabular}{|l|l|l|l}
\hline 4RR4120 & Provide planning/scheduling support & 81 & 010CT98* \\
28JAN99
\end{tabular} \begin{tabular}{|l|l|l|l|l|l|l|l|l|}
\hline 4RR4090 & Develop QA criteria for & 30 & 22APR99 & 03JUN99 \\
\hline
\end{tabular} \begin{tabular}{|l|l|l|l|l|}
\hline 4RR4100 & Procure/fabricate materials/equip & 91 & 22APR99 & 31AUG99 \\
\hline
\end{tabular} \begin{tabular}{|l|l|r|r|r|}
\hline 4RR4080 & Perform safety reviews/walkdowns & 80 & 01MAROO & 21JUN00 \\
\hline
\end{tabular} \begin{tabular}{|l|l|l|l|}
\hline 4RR4130 & Prov input/guidance for projct & 30 & 01MAR00 \\
\hline
\end{tabular} $4 R 010 A 012324$ RLWS ENGINEERING STUDIES 4RR4005 Begin 324 RLWS Engineering \begin{tabular}{|l|l|l|l|l|l|}
\hline 4RR5040 & Prep RLWS Project Plan & 60 & 30 MAR98 $^{*}$ & 22JUN98 \\
\hline $4 R 25000$
\end{tabular}

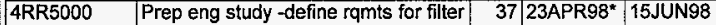
\begin{tabular}{|l|l|r|l|l}
\hline 4RR5010 & Prep eng study -eval exstg system & 55 & 16 JUN98 & 02SEP98 \\
\hline
\end{tabular}

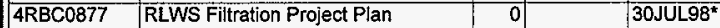
\begin{tabular}{|l|l|r|l|l|}
\hline 4RR5050 & Submit RLWS Project Plan to DOE & 0 & & 30JUL98* \\
\hline
\end{tabular} \begin{tabular}{|l|l|l|l|l|}
\hline 4RR5020 & Prep eng study -det treat/dispsl alt, & 60 & 03SEP98 & 30 NOV98 \\
\hline
\end{tabular}

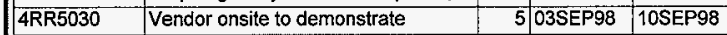
4R010A021324 RLWS DESIGN AND ENGINEERING SUPPORT \begin{tabular}{|l|l|l|l|l|}
\hline 4RR4010 & Begin 324 RLWS Design & 0 & $27 A U G 98$ \\
\hline
\end{tabular} \begin{tabular}{|l|l|r|r|r|}
\hline 4RR9000 & Eval quantities/constituents of waste & 30 & $27 A U G 98$ & $080 C T 98$ \\
\hline
\end{tabular} 4 R010A013 324 RLWS ENVIRONMENTAL DOCUMENTATION \begin{tabular}{|l|l|l|}
\hline 4RR4015 & Begin 324 RLWS Environmental & 27AUG98
\end{tabular} \begin{tabular}{|l|l|r|r|r|}
\hline $4 R R 6000$ & Review modifications for regulations & 10 & 27 AUG98 & 10 SEP98 \\
\hline
\end{tabular} \begin{tabular}{|l|l|r|l|l|}
\hline 4RR6010 & Prepare NEPA documentation & 20 & 11SEP98 & 080CT98
\end{tabular} \begin{tabular}{|l|l|l|l|l|}
\hline 4RR6020 & Modify RCRA closure plan to support & 40 & 11 SEP98 & 05NOV98 \\
\hline
\end{tabular} \begin{tabular}{|l|l|l|l|l|}
\hline $4 R R 6030$ & Prepare Notice of Construction & 50 & 11 SEP98 & 19NOV98 \\
\hline
\end{tabular} \begin{tabular}{|l|l|l|l|l|}
\hline $4 R R 6040$ & Prep or modify SARP for transport of & 50 & $090 C T 98$ & 21DEC98 \\
\hline
\end{tabular} 4RO10A014 324 RLWS USQREVEW Th \begin{tabular}{|l|l|l}
\hline 4RR4020 & Begin 324 RLWS USQ Review & 01010 CT99*
\end{tabular}

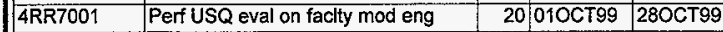
\begin{tabular}{|l|l|l|l|l|}
\hline 4RR7011 & Rev proposed systems against safety & 20 & 010 CT99 & 280CT99 \\
\hline
\end{tabular} \begin{tabular}{|l|l|l|l|l|}
\hline 4RR7021 & Modify baseline as necessary (not & 20 & $010 C T 99$ & $2806 T 99$ \\
\hline
\end{tabular} 4RO 1OAO33 324:RLWS RROCEDURE PREPARATION

\begin{tabular}{|l|l|l|l|l|}
\hline 4RR11000 & Prepare proc for RLWS transfer & 30 & 05 NOV99 & 200EC99
\end{tabular} \begin{tabular}{|l|l|l|l|l|}
\hline 4RR11010 & Prep proc for RLWS treatment & 30 & 05NOV99 & 20DEC99 \\
\hline
\end{tabular} \begin{tabular}{|l|l|r|l|l|}
\hline 4RR11020 & Prep proc for RLWS loadout & 30 & 05 NOV99 & 20DEC99 \\
\hline
\end{tabular} 4RR4025 \begin{tabular}{|l|l|}
\hline 4RR11030 & Prep additional procedures \\
\hline
\end{tabular}

0 05 NOV99

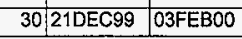

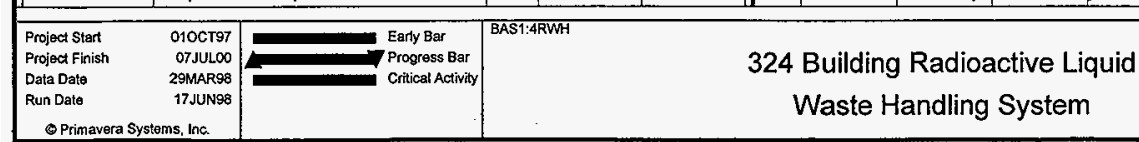

egin 324 RLWS Design/Construct Project Managmnt Identify systems/components to be modified Identify/obtain existing drawings

Eval system capabilities to meet regulatory ramt

Provide planning/scheduling support

- Develop QA criteria for procurement/design/fab

- Procure/fabricate materials/equip 1. Perform safety reviews/walkdowns - Prov input/guidance for projct QA/safety classes

Begin 324 RLWS Engineering Studies

Prep RLWS Project PIan

- Prep eng study -define rqmis for filter system

- Prep eng study eval exstg system capabil/condit

RLWS Filtration Project Plan Complete

Submit RLWS Projec: Plan to DOE

Prep eng study -det treat/disps] alt, systm mods 1 Vendor onsite to demonstrate treatmnt technology

Begin 324 RLWS Design

Eval quantities/constituents of waste

Begin 324 RLWS Environmental Documentation

1 Review modifications for regulations colnpliance

1 Prepare NEPA documentation

Modify RCRA closure plan to support modification

Prepare Notice of Construction

Prep or modify SARP for transport of waste to TF Begin 324 RLWS U\$Q Review

Perf USQ eval on faclty mod eng docs(3)\& ECNs( $(\beta)$

Rev proposed systems against safety auth basis

1 Modify baseline as necessary (not expected)

- Prepare proc for RLWS transfer piping

- Prep proc for RLWS treatment

- Prep proc for RLWS loadout

Begin 324 RLWS Procedure Preparation

a Prep additional procedures

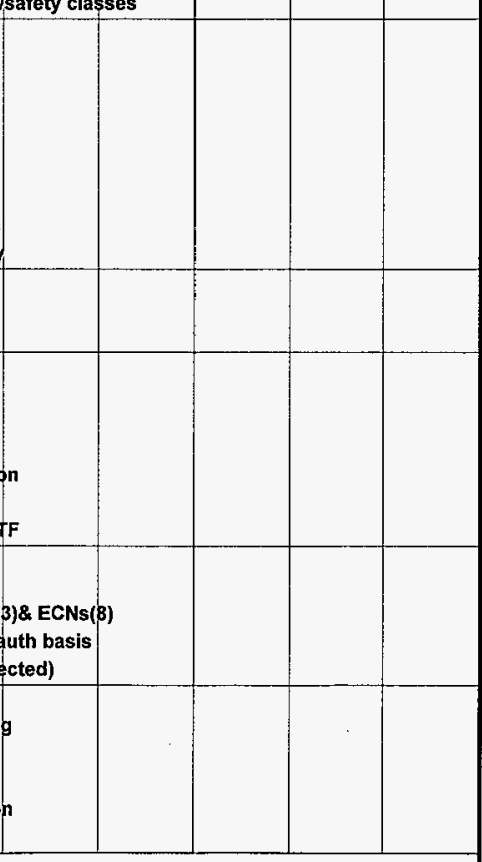

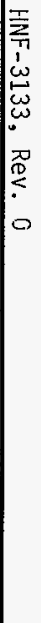




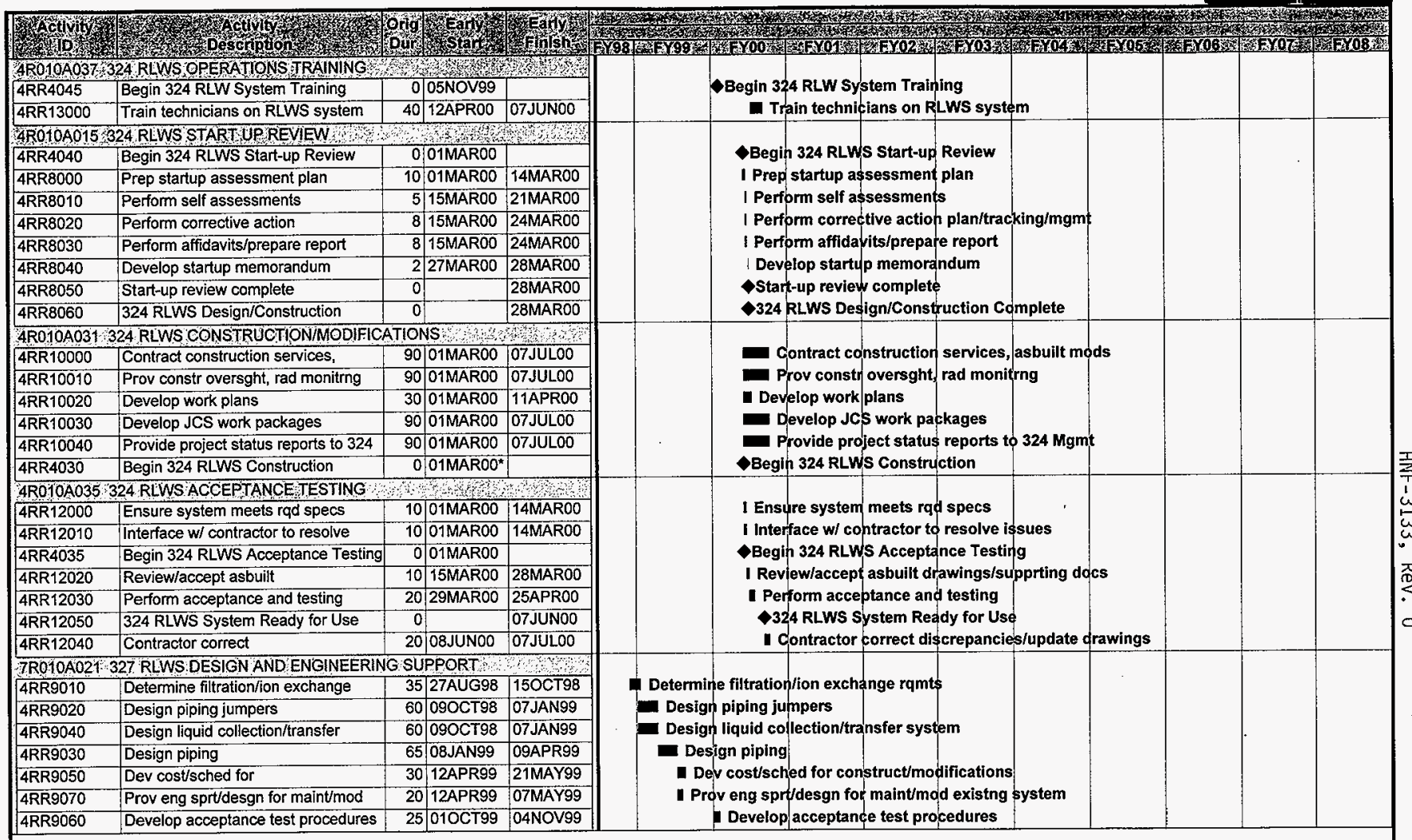




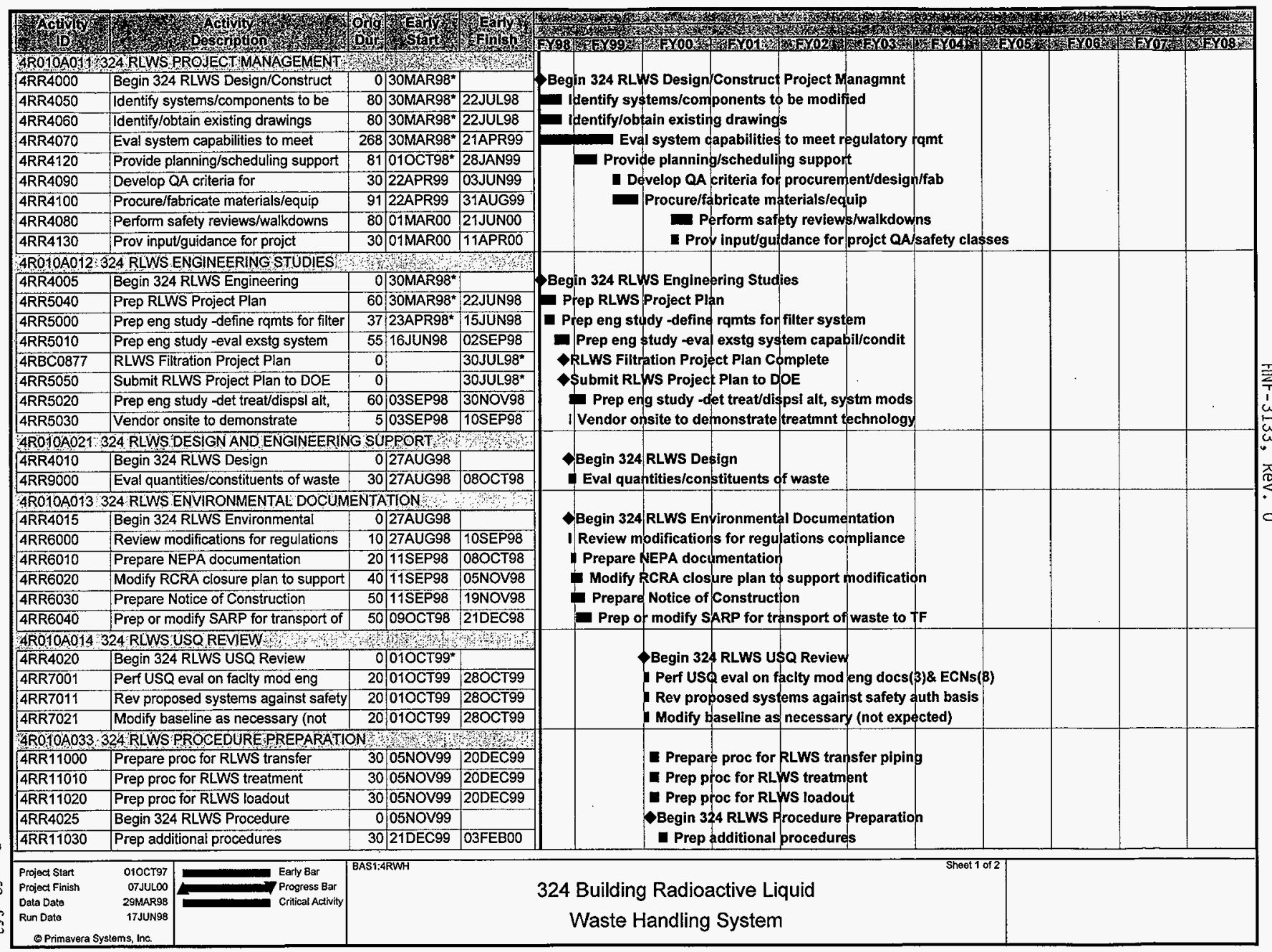




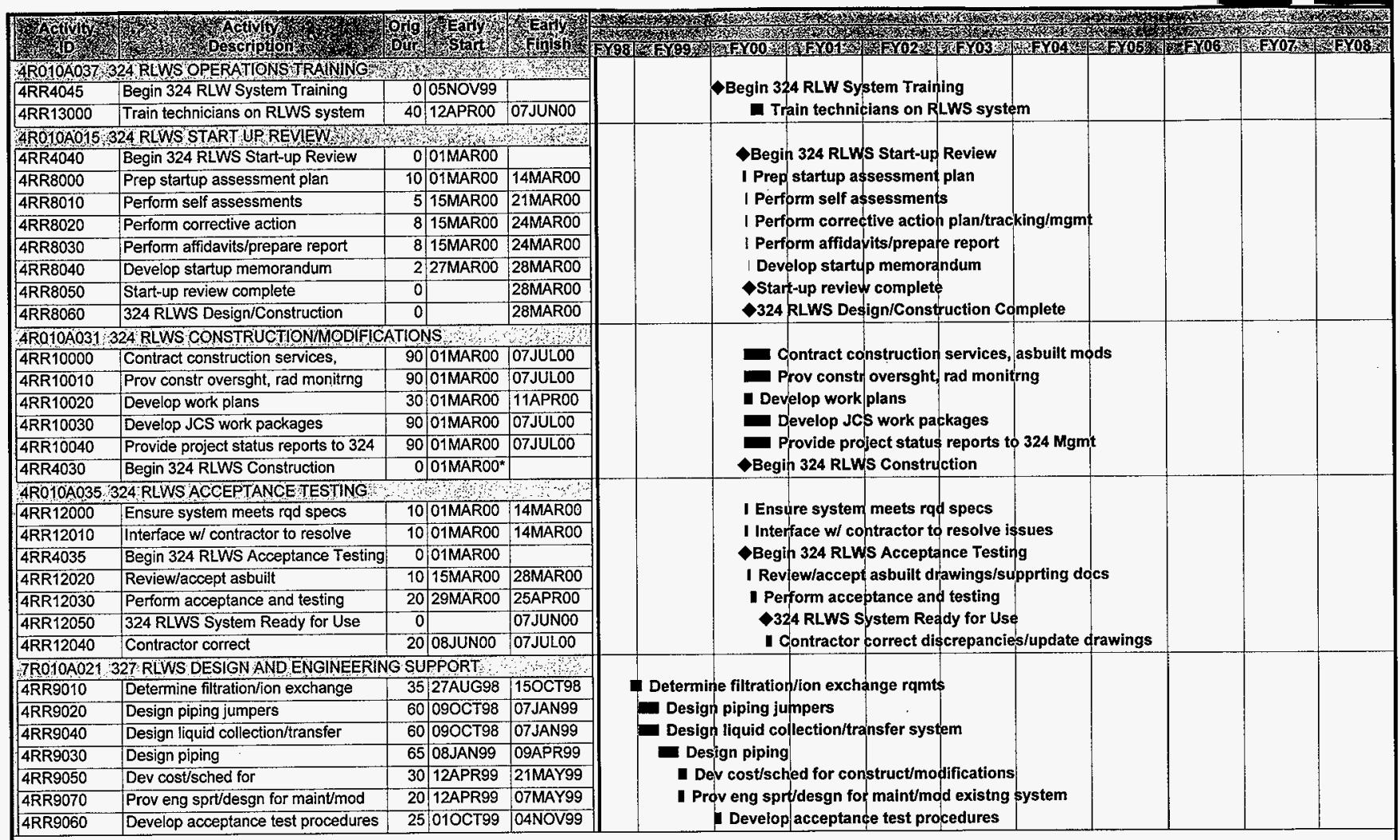




\section{DISTRIBUTION SHEET}

\begin{tabular}{|c|c|c|c|c|c|c|}
\hline \multirow{2}{*}{$\begin{array}{l}\text { To } \\
\text { Distribution }\end{array}$} & & \multirow{2}{*}{\multicolumn{3}{|c|}{$\begin{array}{l}\text { From } \\
324 \text { Subproject Projects }\end{array}$}} & \multicolumn{2}{|l|}{ Page 1 of 1} \\
\hline & 324 & & & & \multicolumn{2}{|c|}{ Date $7 / 28 / 98$} \\
\hline \multirow{2}{*}{\multicolumn{5}{|c|}{$\begin{array}{l}\text { Project Title/Work Order } \\
324 \text { Building Liquid Waste Handling and Removal System Project } \\
\text { Plan }\end{array}$}} & \multirow{2}{*}{\multicolumn{2}{|c|}{$\begin{array}{ll}\text { EDT No. } & 625233 \\
\text { ECN No. } & \text { N/A }\end{array}$}} \\
\hline & & & & & & \\
\hline \multicolumn{2}{|l|}{ Name } & MSIN & $\begin{array}{l}\text { Text } \\
\text { With All } \\
\text { Attach. }\end{array}$ & Text Only & $\begin{array}{l}\text { Attach./ } \\
\text { Appendix } \\
\text { Only }\end{array}$ & $\begin{array}{c}\text { EDT/ECN } \\
\text { Only }\end{array}$ \\
\hline $\begin{array}{l}\text { EJ Bitten } \\
\text { TL Erickson } \\
\text { SD Halstead } \\
\text { JE Ham } \\
\text { RL Hobart } \\
\text { DL Johnson } \\
\text { RM Millikin } \\
\text { SA Norling } \\
\text { DE Rasmussen } \\
\text { JG Riddelle } \\
\text { DH Sandoz } \\
\text { Central Files }\end{array}$ & & $\begin{array}{l}\text { L1-02 } \\
\text { L1-03 } \\
\text { L1-02 } \\
\text { L1-06 } \\
\text { L5-65 } \\
\text { L1-05 } \\
\text { L5-65 } \\
\text { L6-57 } \\
\text { L1-04 } \\
\text { L1-02 } \\
\text { L1-06 } \\
\text { B } 1-07\end{array}$ & $\begin{array}{l}x \\
x \\
x \\
x \\
x \\
x \\
x \\
x \\
x \\
x \\
x \\
x\end{array}$ & & & \\
\hline
\end{tabular}

